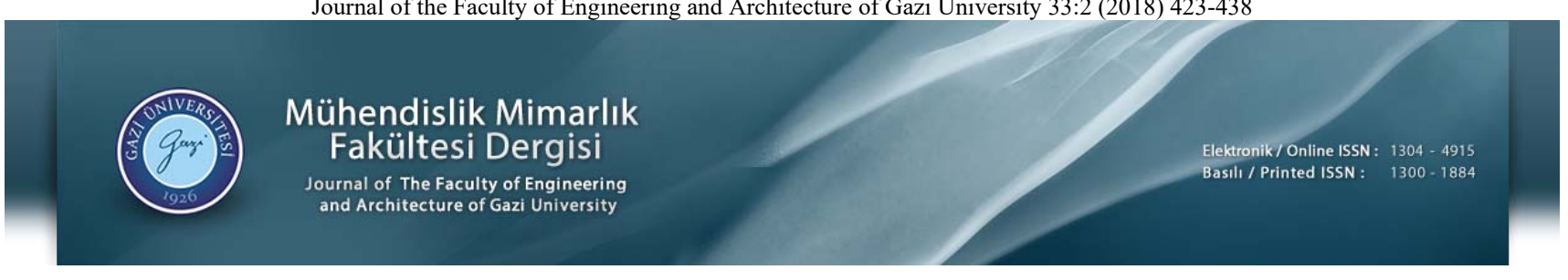

\title{
Kas iskelet sistemi rahatsızlıklarının analizinde yeni bir risk değerlendirme yaklaşımı
}

\author{
Demet Gönen $^{1 *(D)}$, A. Deniz Karaoğlan ${ }^{1}$ (D), M.A. Beyazıt Ocaktan ${ }^{1}$ (D), Ali Oral ${ }^{2}$ (D), Hilal Atıc1 (D), Bünyamin Kaya ${ }^{3}$ (D) \\ ${ }^{1}$ Balıkesir Üniversitesi, Endüstri Mühendisliği Bölümü, 10145, Balıkesir, Türkiye \\ ${ }^{2}$ Balıkesir Üniversitesi, Makine Mühendisliği Bölümü, 10145, Balıkesir, Türkiye \\ ${ }^{3}$ NURSAN Kablo Donanımları San. ve Tic. A.Ş., Tavşanlı OSB, 1. Cadde, No: 5, Tavşanlı, Kütahya, Türkiye
}

\section{Ö N E Ç I K A N L A R}

- Montaj hatlarında kas iskelet sistemi rahatsızlıkları

- Kas iskelet sistemi rahatsızlıklarının değerlendirilebilmesi amacıyla yeni bir risk değerlendirme yöntemi

- Geliştirilen yöntemin REBA, AMS ve EMG ile doğrulanması

Makale Bilgileri

Geliș: 02.08.2016

Kabul: 06.01.2018

DOI:

$10.17341 /$ gazimmfd.416351

Anahtar Kelimeler:

Kas iskelet sistemi rahatsızlıkları, risk değerlendirme, matris yöntemi, fine-kinney yöntemi

\section{ÖZET}

$\mathrm{Bu}$ çalışmada kas iskelet sistemi rahatsızlıklarının değerlendirilebilmesi amacıyla yeni bir risk değerlendirme yöntemi önerilmiştir. Önerilen yöntemde veri toplama aracı olarak Cornell Üniversitesi tarafından geliştirilen ve literatürde yaygın şekilde kullanılan "Kas İskelet Sistemi Rahatsızlık Anketi" çalışmanın amacına uygun olacak şekilde uyarlanarak kullanılmıştır. Yöntem, otomotiv sektöründe kablo üretimi yapan bir yan sanayi kuruluşunda uygulanmış ve montaj hattı çalışanlarının maruz kaldığı kas iskelet sistemi rahatsızlıkları belirlenmeye çalışılmıştır. Hızlı tüm vücut değerlendirme yöntemi (REBA), Anybody modelleme sistemi (AMS) analizleri ve elektromiyografi (EMG) ölçümleri ile önerilen yöntemin doğrulaması yapılmıştır. Elde edilen sonuçlar, önerilen yöntemin iş yeri ortamında işe bağlı olarak ortaya çıkan kas iskelet sistemi rahatsılıklarının (KİSR), etkilenen kişi yoğunluğu da dikkate alınarak önceliklendirilmesinde başarılı bir biçimde kullanılabileceğini göstermiştir.

\section{A new risk assessment approach for the analysis of musculoskeletal disorders}

\section{H I G H L I G H T S}

- Musculoskeletal disorders in assembly lines

- A new risk assessment method for assessing musculoskeletal disorders

- Confirmation of the proposed method with REBA, AMS and EMG

\section{Article Info}

Received: 02.08.2016

Accepted: 06.01.2018

DOI:

10.17341/gazimmfd.416351

Keywords:

Musculoskeletal system

disorders,

risk assessment,

matrix method,

fine-kinney method

\section{ABSTRACT}

In this study a new risk assessment method for the evaluation of musculoskeletal disorders is proposed. "Musculoskeletal Discomfort Questionnaire" which was developed by Cornell University and widely used in the literature is adapted to fit the purpose of the study, and used as the data collection tool of the proposed method. The application of this method is conducted in a company that produces cable harnesses in the automotive supply industry and the musculoskeletal disorders of assembly line employees were identified (or diagnosed). The verification of the method was made using Rapid Entire Body Assessment (REBA), AnyBody Modelling System (AMS) analysis and Electromyography (EMG) measurements. The results show that the proposed method can be used successfully in prioritizing the work-related musculoskeletal system disorders (MSD), taking into account the intensity of the affected person.

\footnotetext{
*Sorumlu Yazar/Corresponding Author: dgonen@balikesir.edu.tr / Tel: +90 2666121194
} 


\section{GIRIŞS (INTRODUCTION)}

İşle ilgili kas iskelet sistemi rahatsızlıkları (KİSR) terimi; "kaslar, tendonlar, iskelet, kıkırdak, bağ ve sinirler gibi hareketi sağlayan sistemlerdeki sağlık problemleri" olarak tanımlanmaktadır [1]. Emek yoğun üretim yapılan montaj hatlarında, çalıșanların tekrarlı hareketler ve/veya uygun olmayan duruş pozisyonlarında uzun süre çalışmalarına bağlı olarak kas ve iskelet sistemi rahatsılıkları gözlenmektedir [2, 3]. Montaj hattı çalışanlarının her biri farklı demografik, fizyolojik ve antropometrik özelliklere sahiptir. Farklı çalışma pozisyonları bir çalışanda sağlık sorununa ve/veya meslek hastalığına neden olurken, aynı fiziksel şartlar başka bir çalışanda sağlık sorununa neden olmayabilir. Bunun yanında montaj hattı çalışanının yaşamış olduğu sağlık probleminin doğrudan iş ile ilgili olup olmadığını veya bu problemin çalışanların genelini ilgilendiren bir sağlık problemi olup olmadığını belirlemek zordur. İş sağlığı ve güvenliği uygulamaları öncelikle genel iş sağlığı ve güvenliğine önem vermekte, bu yöntemlerle çözüm bulunamayan iş güvenliği risk unsurları için kişisel koruma tedbirleri ile önlem alınmaktadır. Montaj hatt1 tasarımında farklı antropometrik özelliklere sahip çok sayıda çalışanın her birine hitap edecek bir hat tasarlamak her zaman mümkün değildir. Tasarım yaparken çalışanların uzanma, tutma ve ekipman kullanma gibi yeteneklerinin yanı sira yorgunluk ve kas-iskelet sistemi rahatsızlikları yaşamadan işlerini ne kadar süre yapabilecekleri dikkate alınmalıdır. Çünkü uygun olmayan tasarımlar performansı düşürürken üretim sürecini de yavaşlatmaktadır [4]. Bu çalışmada yukarıdaki tanıma uyan bir işletme ele alınmış ve hat tasarımı yaparken çalışanların geneli dikkate alınarak, hangi vücut bölümlerinin göz önünde bulundurulması gerektiğini belirlemek üzere Risk Değerlendirmesi için Modifiye Matris Yöntemi (RDMMY) adı verilen yeni bir risk değerlendirme yaklaşımı önerilmiş ve test edilmiştir. $\mathrm{Bu}$ çalışmada geliștirilen yöntem anket verilerini kullanarak hesaplama yapan kantitatif bir yöntemdir ve yöntemin geliştirilmesinde Fine-Kinney ve Matris Yönteminden esinlenilmiştir.

Risk değerlendirme ve analizi için sıklıkla kullanılan FineKinney metodu; olasılık, risk ve şiddet terimleriyle risk skoru hesaplayan ve matematiksel olarak değerlendiren bir yöntemdir $[5,6]$. Pratikte çok kullanılan bir yöntem olmasına karşın, literatürde sadece Fine-Kinney metodunun kullanıldığı çalışma sayısı azdır. Băbuţ vd. [7] Fine-Kinney metodunun avantajlarını, dezavantajlarını ve sınırlarını tartışmıştır. Stankovic ve Stankovic [8] tehlikenin açığa çıkabileceği işyerlerinde iş sağlığı, çevre sağlığı ve ateşten korunmada risk değerlendirme için Fine-Kinney ve AUVA (Mesleki Riskler İçin Avusturya Sosyal Sigortalar Kurumu) metotlarını risk matrisi oluşturarak kullanmış ve iki yöntemi kıyaslamıştır. Gürcanlı vd. [9] temel amacı bir inşaat projesindeki iş güvenliği maliyetlerini tahminlemek olan çalışmalarında faaliyetlerin risk değerlendirmesi için Fine-Kinney ve L Matris yöntemlerini kullanmış, risk skorlarını kıyaslamıştır. Oturakçı vd. [10] daha yüksek olasılık ve daha sık frekanslı tehlikelerin skaladaki puanlarını yükselterek, Fine-Kinney metoduna yeni bir yaklaşım getirmiş ve bu yaklaşımı orta ölçekli bir işletmede uygulamıştır. Akdağ vd. [11] büyük ölçekli bir elektrik elektronik işletmesindeki iş sağlığı ve güvenliği alanındaki riskleri, Fine-Kinney metoduyla analiz ederek değerlendirmiștir. Kokangül vd. [12] Fine-Kinney metodunda tehlike risk sınıflarının ve önem düzeylerinin Analitik Hiyerarşi Süreci Metodu ile birlikte belirlenebileceği bir yaklaşım geliştirmiştir.

S1k kullanılan bir diğer yaklaşım olan"Risk Değerlendirme Matrisi”, ABD Askeri standardı MIL-STD-882 olarak da bilinen sistem güvenlik program gereksinimini karşılamak maksadıyla geliştirilmiştir. Matris yöntemi, bir olayın gerçekleşme olasilığ ile gerçekleştiği taktirde meydana getireceği şiddetin bileşkesi ile hesaplanan riskin kabul edilebilir olup olmadığını belirlemek için kullanılmaktadır. Matris yöntemi L tipi (yaygın olarak 5x5 matris) ve $\mathrm{X}$ tipi olmak üzere ikiye ayrılır. $\mathrm{L}$ tipi matris yönteminde her bir tehlike için belirlenen risklere yönelik öngörülen olasılık ve şiddet değerlerinin çarpımı ile elde edilen risk skorunun, değerlendirme matrisinde yer aldığ risk bölgesi belirlenmekte ve buna göre gerekli eyleme karar verilmektedir. $\mathrm{X}$ tipi matris yönteminde ise; en az 5 yıllık geçmiş olayların neden-sonuç ilişkilerinin belirlenmesi, buna göre olayların meydana gelme ve tekrarlanma olasılıklarının araştırılması ve alınacak önlemlerin maliyet analizinin yapılmasına ihtiyaç duyulmaktadır. $\mathrm{Bu}$ yöntemde, riskin gerçekleşmesi durumunda ortaya çıkacak zararın maliyeti ile riski ortadan kaldırılmaya yönelik alınacak önlemlerin maliyetlerinin kıyaslamas1 yapilır $[13,14]$. Woodruff $[15]$ riskin seviyesini belirlemek yerine "Dayanılmaz", "Tolere edilebilir" ve "Kabul Edilebilir" risk bölgeleri belirlemiş ve literatürde yaygın kullanılan risk değerlendirme matrislerine göre oldukça farklı bir matris önermiștir. Bu matriste bir olayın olma olasıllı̆ını $0,01-100.000 .000$ arasında, şiddetini ise 0,0001-10 arasında ölçeklendiren yeni bir değerlendirme matrisi önermiştir. Cox [16] risk matrislerinin bazı matematiksel özelliklerini incelemiş ve risk matrislerinin sahip olduğu kısıtlamaları göstererek, bu kısıtlamaların göz önünde bulundurularak kullanılması gerektiğini ileri sürmüştür. Ristic [17] $\mathrm{ABD}$ Askeri Standardı olan MIL-STD-882, Avustralya Standardı olan AS/NZS 4360:200, İş sağlığı güvenliği yönetim sistemi olan OHSAS v.b. standartları ve yaygın kullanılan matris yöntemlerini farklı matris boyutlarında $(3 \times 3,4 \times 4,5 \times 5,5 \times 4$ ve $6 \times 4)$ ele alarak birlikte değerlendirmiş ve matrislerin boyutlandırmasının performansına etkisi üzerine çalışmıştır. Duijm [18] risk değerlendirme matrislerinin kullanımı ve tasarımı üzerine öneriler geliştirmiştir. ICAO (International Civil Aviation Organization) [19], ISO 17666 (International Organization Standarts) [20] ve NASA (National Aeronautics and Space Administration) [21] standartlarındaki gibi farklı risk koşullarında risk değerlendirmede kullanılabilecek standart bir çok risk matrisi literatürde bulunmaktadır. 
$\mathrm{Bu}$ çalışmada önerilen RDMMY yönteminin kullanılabilmesi için gerekli olan verilerin toplanmasında anket yönteminden faydalanılmıştır. Literatürde kas iskelet sistemi rahatsızlıkları ile ilgili yaygın olarak kullanılan anketler; İskandinav Kas İskelet Sistemi Anketi (Nordic Musculoskeletal Questionnaire), Alman Kas İskelet Sistemi Anketi (Dutch Musculoskeletal Questionnaire) ve Cornell Kas İskelet Sistemi Rahatsızlık Anketi (Cornell Musculoskeletal Discomfort Questionnaire)'dir. Kuorinka vd. [22] tarafından geliştirilen İskandinav Kas İskelet Sistemi Anketi, kas iskelet sistemi semptomlarının şiddeti ve etkisini değerlendirmek için kullanılan anketlerden biridir. İskandinav Kas İskelet Sistemi Anketinde iş çevresinde en sık karşılaşılan semptomlar üzerine yoğunlaşılmış ve farklı bir çok çalışma ortamında uygulanmıștır Chandrasakaran vd. [23] yarı iletken sektöründe çalışan kadınların işle ilgili kas iskelet sistemi rahatsızlıklarını ve ergonomik risk faktörlerini belirlemek için, Simu vd. [24] Romanya'daki diş hekimleri arasında kas iskelet sistemi rahatsızlıklarının varlığını belirlemek için, Smith vd. [25] Japonya özelinde Asyalı hemşirelerin kas iskelet sistemi rahatsızlıkları risk faktörlerini belirlemek için İskandinav Kas İskelet Sistemi Anketini kullanmışlardır. Pugh vd. [26] hemşireler için İskandinav Kas İskelet Sistemi Anketinin yeni, online ve geçerli yeni bir versiyonunu sunmuştur. Kahraman vd. [27], bu anketin Türkiye'de de kullanılabilmesi için Türkçe'ye adapte ederek, güvenirliğini test etmiştir. Hildebrandt [28] tarafından geliştirilen Alman Kas İskelet Sistemi Anketi ise çalışanların işle ilişskili kas iskelet risk faktörlerinin ve semptomlarının hızlı bir şekilde ölçülmesine olanak sağlamaktadır. Hildebrandt vd. [29] hemşireler, tersane işçileri, ofis çalışanları ve metal işçileri başta olmak üzere 24 meslek grubundan 1575 çalışan üzerinde kas iskelet iş yükü ve ortak çalışma koşulları risklerinin belirlenmesi amacıyla anketi uygulamıştır. Ikhar vd. [30] pamuk çıkrık dokuma çalışanları, Vahdati vd. [31] farklı uzmanlık alanlarında görevli asistan doktorlar, Bos vd. [32] farklı hemşire grupları üzerinde anketi uygulamıştır. İskandinav ve Alman Kas İskelet Sistemi anketlerinin analizi, anket sorularına verilen yanıtların yüzde frekans değerlerine göre istatistiksel olarak gerçekleştirilmektedir. Hedge vd. [33] tarafından geliştirilen Cornell Kas İskelet Sistemi Rahatsızlıkları Anketi temel olarak İskandinav Kas İskelet Sistemi Anketine dayanmaktadır. Hedge vd. [33] ekran önü çalışmalarında, Menzel [34] sağlık sektöründe hemşirelerin, Jansen [35] montaj hattı çalışanlarının kas iskelet sistemi rahatsızlıklarının belirlenmesinde anketi kullanmıştır. Anket, Erdinç vd. [36] tarafından Türkçe'ye de çevrilerek, anketin geçerliliği ve güvenirliği test edilmiştir. İskandinav ve Alman Kas İskelet Sistemi anketlerinin değerlendirme yöntemlerinden farklı olarak Cornell Kas İskelet Sistemi Rahatsızlıkları Anketi skoru sistemine dayanmaktadır. Bu anketin değerlendirilmesinde farklı vücut bölümlerinin toplam rahatsızlık skoru sıklık, şiddet, rahatsızlığın işe etkisi skorlarının çarpımıyla bulunmakta ve ankette değerlendirilen tüm vücut bölümlerinin toplam skoruna oranla en yüksek yüzde skora sahip bölümleri, en ciddi probleme sahip vücut bölümlerini belirlemede kullanılmaktadır. Cornell Kas İskelet Sistemi Rahatsızlığ1 anketinin değerlendirme sistemi Alman ve İskandinav anketleriyle kıyaslandığında sadece frekanslara bakmaktan ziyade skor puanı hesaplaması nedeniyle daha kapsamlı bir değerlendirme sistemine sahiptir denebilir.

$\mathrm{Bu}$ çalışmada, iş ortamının KİSR'larının azaltılmasına yönelik olarak düzenlenmesinde, çalışanların hangi vücut bölümlerinin öncelikle dikkate alınması gerektiğini belirlemek amacıyla yeni bir risk değerlendirme yöntemi (RDMMY) önerilmiștir. $\mathrm{Bu}$ yöntem genel bir risk değerlendirme yöntemi olmaktan ziyade, daha çok ergonomik risk değerlendirme yöntemi olarak sınıflandırılabilir. Bu yöntemi uygulayabilmek için Cornell Üniversitesi tarafindan geliştirilmiş olan anket, RDMMY'ne uygun veri sağlayacak şekilde modifiye edilmiş ve montaj hattı çalışanları üzerinde uygulanmıştır. Önerilen yöntem, hızlı tüm vücut değerlendirme (REBA) yöntemiyle duruş analizleri, elektromiyografi (EMG) ölçümleri ve Anybody modelleme sistemi (AMS) analizleri ile doğrulanmıştır.

\section{RISSK DEĞERLENDİRMESİ İÇIN MODİFIYE MATRÍS YÖNTEMİ (RDMMY) (MODIFIED MATRIX METHOD FOR RISK ASSESSMENT (MMMRA))}

$\mathrm{Bu}$ çalışmada montaj hattı çalışanlarının rahatsızlık frekansı, şiddeti ve şikayetlerinin işle ilgi derecelerine göre hangi vücut bölümlerinin risk altında bulunduğunun hesaplanabilmesi amaciyla yeni bir risk değerlendirme yöntemi önerilmiş ve bu yönteme dayanarak analizler yapılmıştır. Ölçek olarak Cornell Kas İskelet Sistemi Rahatsızlığı Anketi kullanılmıştır [37]. Ancak, orijinal ankette 3'lü likert ölçeğine göre verilen bölümler 5'li ölçeğe çevrilerek, cevapların hassasiyeti arttırılmıştır. Bunun yanında orijinal anketin 3. bölümünde ağrının iş yapma kabiliyetine etkisi sorulurken; bu çalışmanın amacına göre düzenlenmiş yeni ankette ağrının işle ilgisi sorulmaktadır. Burada amaç, kişilerin kronikleşmiş ve yaptığı işle ilgisini kendince belirtebildiği özel rahatsızlıkların (eklemlerde kireçlenme, romatizma, travmaya bağlı yaralanmalar v.b.) iş ortamından kaynaklı rahatsızlıklara göre risk değerlendirmesinde daha az öncelik skoru almasını sağlamaktır. Kullanılan anket formu Şekil 1 'de verilmiştir.

Anketin 1. bölümünde, ankete katılan kişiler belirtilen vücut bölgelerindeki ağrıyı hangi sıklıkta yaşadığını puanlamaktadır. Aynı şekilde anketin 2. ve 3. bölümlerinde ise sırasıyla belirtilen vücut bölgelerinde yaşanan ağrının şiddeti ve hissedilen ağrının işle ilgisi kullanıcılar tarafından puanlanmıştır. Anketi cevaplayan katılımcıların verdikleri cevaplara göre hangi vücut bölgeleri üzerinde ergonomik anlamda risk bulunduğunu tespit etmek amacıyla yeni bir risk değerlendirme matrisi önerilmiştir. $\mathrm{Bu}$ matris iş sağlığı ve güvenliği (İSG) alanında risk değerlendirme amacıyla yaygın olarak kullanılan Matris Yöntemi ve Fine-Kinney yöntemlerinden esinlenilerek geliştirilmiştir. 


\begin{tabular}{|c|c|c|c|c|c|c|c|c|c|c|c|c|c|c|}
\hline \multicolumn{5}{|c|}{ 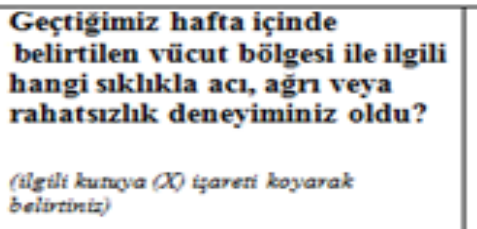 } & \multicolumn{5}{|c|}{ 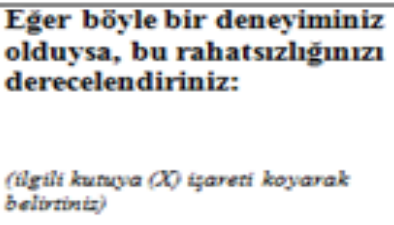 } & \multicolumn{5}{|c|}{ 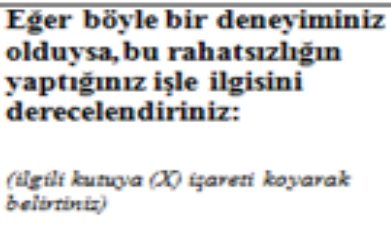 } \\
\hline \multicolumn{5}{|c|}{ Puan } & \multicolumn{5}{|c|}{ Puan } & \multicolumn{5}{|c|}{ Puan } \\
\hline 1 & 2 & 3 & 4 & 5 & 1 & 2 & 3 & 4 & 5 & 1 & 2 & 3 & 4 & 5 \\
\hline 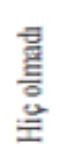 & 蛋 & 摒咅 & 退 명 & 造 & $\frac{\text { Zे }}{\text { eे }}$ & Z & 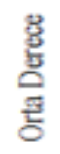 & 焉 & 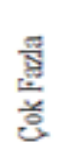 & 兑 & Z & 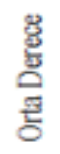 & 骂 & 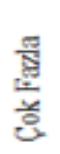 \\
\hline
\end{tabular}
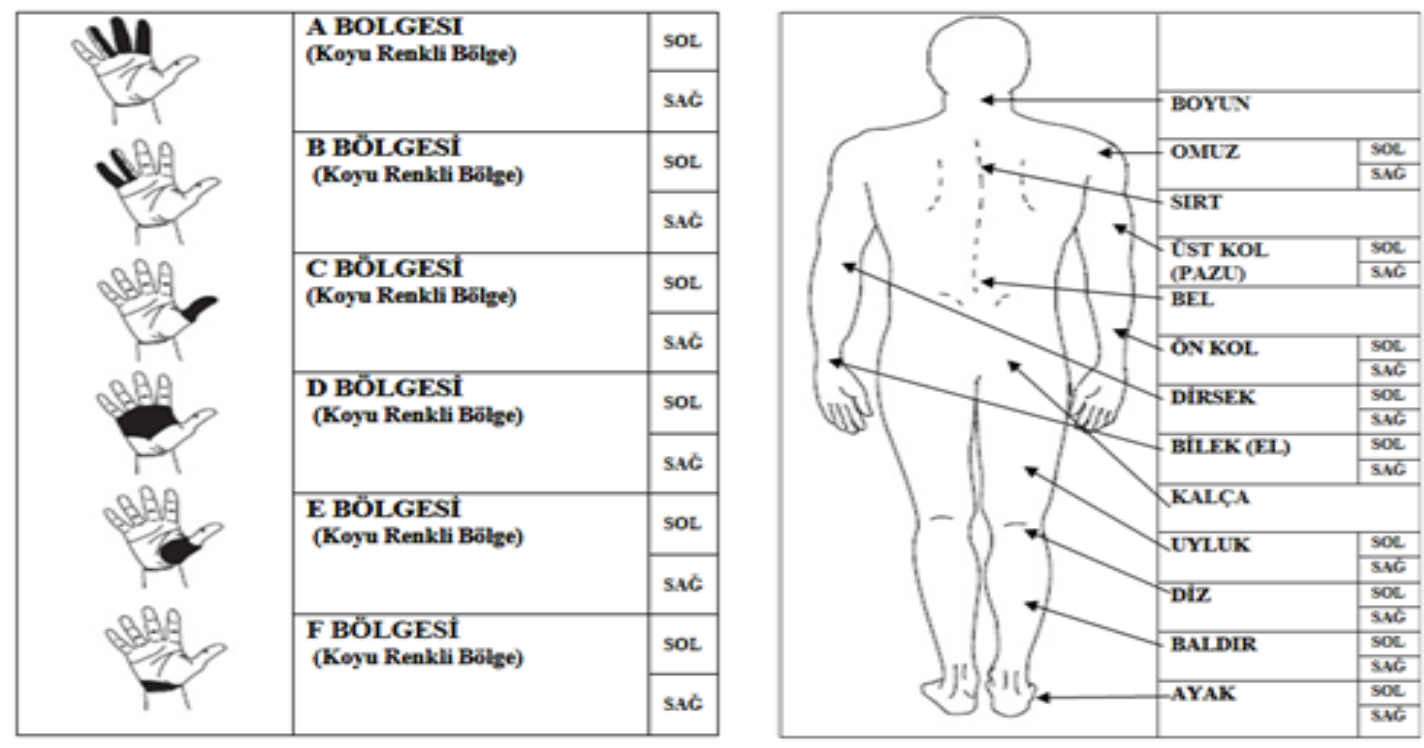

Şekil 1. Cornell Kas İskelet Sistemi Rahatsızlık Anketi (Cornell Musculoskeletal Discomfort Questionaire)

Risk, bir olayın meydana gelme olasılığı ile meydana gelmesi durumunda ortaya çıkaracağı zararın (şiddet) bir bileşkesi şeklinde tanımlanabilir. Nihai amaç tüm risklerin ortadan kaldırılmasıdır, ancak bunun mümkün olmadığ veya zaman, maliyet v.b. farklı kısıtların olduğu durumlarda risklerin değerlendirilerek önceliklendirilmesi gerekmektedir. Literatürde İSG alanında kullanılan risk değerlendirme yöntemleri; nitel, nicel ve karma yöntemler olarak sinıflandırılmaktadır.

Nitel yöntemlerden Çeklist (Check-List), Olursa Ne Olur Analizi (What-If Analysis), Emniyet Denetimleri (Safety Audits), Görev Analizi (Task Analysis), Tehlike ve İşletilebilirlik Analizi (Hazard and Operability Studies HAZOP) yaygın olarak kullanılan yöntemlerdir. Ancak bu yöntemlerin değerlendirme sistematiği sayısal hesaplamalara değil sözel ifadelere dayalıdır ve risk skoru hesaplanmaz [38, 39].

Nicel yöntemler ise temelde olasıllk ve şiddetin bileşkesinin alınması esasına dayanarak risk değerlendirmesi yapar. En yaygın kullanılan yöntemlerden biri Matris Yöntemidir. En sık kullanılan 5x5 Matris Yönteminde olasılık 1-5 arasında puanlanırken, çok nadiren (örneğin yılda 1 veya daha az) gözlenen olaylara 1 puan, çok s1k bir biçimde gözlenen olaylara 5 puan verilmektedir. Ardından risk skoru; Risk Skoru=OlasılıkxŞiddet formülü ile hesaplanarak risk derecelendirilmektedir [38, 39]. Olasılik ve şiddet değerlerinden en az birinin orta değer olan 3 değerinin altında olması; zayıf olasılık veya düşük şiddet anlamına gelir ve bileşkesi $2 \times 3=6$ 'dır. $\mathrm{Bu}$ nedenle, Matris Yönteminde 6 ve altında hesaplanan risk skoru kabul edilebilir risk olarak değerlendirilmektedir. Hem olasılık hem de şiddet değerinin 1 olması durumunda ise hesaplanan risk skoru anlamsız olarak değerlendirilir. Olasılık ve/veya şiddet değerlerinden en az bir tanesi minimum 3 iken bileşke skor 15 ve üstü değer alıyorsa, bu skor yüksek riskli grubu göstermektedir. $\mathrm{Bu}$ durumda oluşan 15 ve üzeri risk skoru önemli risk grubu olarak kabul edilir. Olasılık ve şiddet değerlerinin her ikisinin de 5 olduğu durumda hesaplanabilen 25 risk skoru ise kabul edilemez risk grubudur ve bu durumda çalışma derhal durdurulur. Bunların dişında hesaplanan riskler ise orta düzey risk grubuna girer. 
Oransal Risk Değerlendirme Metodu (The Proportional Risk-Assessment Technique) risk skorunu, Risk Skoru= OlasılıkxŞiddetxFrekans formülü ile hesaplamaktadır. Her bir bileşen 1-10 arasında değer alabilmekte ve dolayısıyla risk skoru 1-1000 arasında bir değer almaktadır. 1-200 arasındaki risk skoru kabul edilebilir risk olarak sinıflandirılır. 200-300 skoru 1 yıldan önce; 300-500 skoru 1 aydan önce, 500-700 skoru 1 günden önce tedbir alınmas1 gerektiği anlamına gelirken; 700-1000 arasında bir risk skoru hesaplanması durumunda ise iş durdurularak hemen önlem alınması gerekir [38]. Ayrıca Supciller ve Abali [40] geleneksel yöntemin dezavantajlarını gidermek üzere bulanı mantı kullanan Bulanık Oransal Risk Değerlendirme Metodunu (The Fuzzy Proportional RiskAssessment Technique) önermiştir.

Fine-Kinney yöntemi de aynı formülü kullanmakla birlikte bileşenlerinin değer aralıkları farklıdır. Olasılık 0,2-10, frekans 0,5-10, şiddet 1-100 arasında eşit olmayan aralıklarla değer alır ve risk skoru 400'den büyük hesaplanırsa kabul edilemez risk, 200-400 kısa vadede iyileştirilmesi gereken risk, 70-200 uzun dönemde iyileştirilebilecek risk ve 70 altında hesaplanan risk skoru ise gözetim altında tutulacak risk grubunu göstermektedir $[5,7,41]$. Ayrıca son y1llarda analitik hiyerarşi süreci kullanarak riskleri önceliklendiren ve Fine-Kinney metodu ile değerlendiren farklı yaklaşımların yer aldığı çalışmalar da görülmektedir [12].

Hata Türü ve Etkileri Analizi (Failure Mode and Effects Analysis-FMEA) ise risk skorunu, Risk Skoru=OlasılıkxŞiddetxTespit Edilebilirlik formülü ile hesaplamaktadır. $\mathrm{Bu}$ yöntemde risk bileșenlerinin her biri 1-10 arasında değer almakta, dolayısıyla risk skoru 1-1000 arasında hesaplanabilmektedir. 1-50 aras1 risk skoru kabul edilebilir risk grubunu ifade ederken; 50-100 orta, 100-200 yüksek ve 200-1000 arası risk skoru ise çok yüksek risk sınıfinı göstermektedir [42].

Matris Yöntemi uygulamada en yaygın kullanılan yöntemlerden biri olmasına karşın bu yöntemde skor hesaplamada kullanılan olasılık ve frekans kavramları birbirine karışmaktadır. Çünkü, matris yönteminin kullandığı olasılık tablolarında puanlama bir olayın yaşanma sıklığına göre verilmekte ve eğer bir olay sıklıkla yaşanmışsa olasılığ fazla, nadiren yaşanmışsa olasılığı az olarak değerlendirilmektedir. Ancak, bir olayın s1klıkla gözlenmesi, olasılığının da yüksek olduğunu her zaman göstermez. Örneğin, deprem olma olasılığı yüksek olan bir bölgede onlarca y1l boyunca hiç deprem yaşanmamış olması, bunu matris yöntemine göre kabul edilebilir risk bölgesinde hesaplamaktadır ki bu yanıltıcı bir sonuçtur. $\mathrm{Bu}$ duruma bir örnek de çalışma ortamından verilebilir. Bir iş yerinde her dakika iş kazası olmaz, ancak her dakika iş kazası olma olasılığı vardır. Buna göre olasılık ve frekans farklı kavramlardır. Fine-Kinney yöntemi de olasılık ve frekans bileşenlerini ayrı ayrı dikkate alarak risk skorunu, olasılık $\times$ şiddet $\times$ frekans formülü ile hesaplamaktadır [6].

Önerilen RDMMY yönteminin geliştirilmesinde Matris Yönteminde olduğu gibi 1-5 arasında ölçeklendirmeden yararlanılmıştır. Ancak, risk bileşenlerini olasılık ve şiddet değil; etkilenme derecesi ve etkilenen kişi yoğunluğu oluşturmaktadır. Ayrıca, bu bileşenlerin değerleri doğrudan risk analizi yapan kişi tarafindan belirlenmemektedir. Bileşenlerin değeri, kas iskelet sistemi rahatsılıkları anketinin belirli sayıda çalışana uygulanmasının ardından elde edilen verilerden hesaplanan skor değerlerinden elde edilmektedir. Etkilenme derecesi hesabında frekans değeri de çarpan olarak kullanılmakta ve bu yönüyle Fine-Kinney yöntemine benzemektedir. Ancak, literatürdeki yöntemler önemli iki risk bileşeni olan ağrının işle ilgisi ve etkilenen kişi yoğunluğunu dikkate almamaktadır. Birgören [41] de Fine-Kinney metodunda risk faktörlerinin hesaplanması zorluklarını tartışmış ve etkilenen kişi sayısının klasik hesaplamalarda ortaya çıkarttığı yanlış değerlendirmelere dikkat çekmiştir. Önerilen RDMMY literatürden farklı olarak, ağrının işle ilgisi ve etkilenen kişi yoğunluğunun da dikkate alınması, yöntemi literatürdeki diğer kantitatif tekniklerden ayırmaktadır. Ayrıca bu yöntemi uygulayabilmek için tek başına bir bireyin değil, belirli sayıda bireyin incelenmesi ve bunlara ait ortalama değerlerin kullanılması gerekmektedir. Dolayısıyla iş sağlığı ve güvenliğinde toplu korumaya öncelik verme prensibi dikkate alınmaktadır. Önerilen RDMMY, FineKinney ve Matris Metodlarından esinlenmekle birlikte gerek risk skoru hesabı, gerekse de kullanım alanı açısından bu iki metoda göre farklılık göstermektedir. HAZOP yönteminin kimya sektörüne özel geliştirilmiş olması gibi; RDMMY, KISR'na yönelik olarak ergonomik risk değerlendirmeye odaklanan ve bu amaca özel geliştirilmiş değerlendirme matrisi kullanan bir yöntemdir. Bu bağlamda literatüre ergonomik risk değerlendirme konusunda katk1 sağlamaktadır. Geliştirilen RDMMY'de önerilen değerlendirme matrisi bileşenleri, etkilenme derecesi ve etkilenen kişi yoğunluğundan oluşmaktadır. Bu bileşenlerin aldığı değerler anketin Şekil 1'de belirtilen üç bölümüne verilen cevaplardan elde edilmektedir. Etkilenme derecesi

Tablo 1. Etkilenme derecesi değerlendirme kriterleri (Assessment criteria for exposure degree)

\begin{tabular}{lll}
\hline Grup Puan1 & Aralık & Anlamı \\
\hline 1 & 1 değeri & Anlamsız \\
2 & 2-7 aras1 & Düşük Düzey Tehlike \\
3 & 8-26 arası & Orta Düzey Tehlike \\
4 & $27-63$ arası & Yüksek Düzey Tehlike \\
5 & 64-125 aras1 & Çok Yüksek Düzey Tehlike \\
\hline
\end{tabular}


Eş. 1'e göre hesaplanmaktadır.

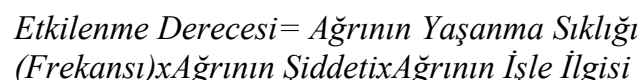

Etkilenme derecesi hesaplanırken ankete katılanlar tarafından "1" puan verilen cevaplar dikkate alınmamış, sadece "1" puanın üzerindeki cevaplar dikkate alınmıştır. Çünkü, anket sorusuna "1" puan verilmesi herhangi bir sorun yaşanmadığ 1 anlamına gelmektedir. Bu hesaba göre, eğer ilgili vücut bölümünde bir sorun yaşanıyorsa, etkilenme derecesinin her zaman 1'den büyük çıkması gerekir. Buna karşın, ilgili vücut bölümü için, ankete katılan tüm katılımcıların etkilenme derecesi bileşenlerine verdikleri cevaplarının 1 puan olması durumunda, ilgili vücut bölümünün etkilenme derecesi bileşen ortalaması "1" olarak kabul edilir. Bu değerlendirme matrisinde, etkilenme derecesi 5 farklı tehlike kategorisinden oluşmaktadır (Bkz. Tablo1). Anketi cevaplayan herkesin ağrının yaşanma sıklığına, şiddetine ve ağrının işle ilgisine sırasıyla "1" puan vermesi durumunda beklenen "etkilenme derecesi" değeri $1 \times 1 \times 1$ 'den " 1 " olarak hesaplanır ve bu ergonomik anlamda risk değerlendirmesindedikkate alınması anlamsız bir değerdir. Çünkü bu sonuç, ankete katılanların herhangi bir rahatsızlık yaşamadığı anlamına gelir. Aynı şekilde herkesin 2 cevabinı vermesi durumunda beklenen skor $2^{3}=8,3$ cevabinı vermesi durumunda beklenen skor $3^{3}=27$, 4 cevabını vermesi durumunda beklenen skor $4^{3}=64$ ve son olarak 5 cevabını vermesi durumunda beklenen skor $5^{3}=125$ şeklinde gerçekleşecektir. Bu üst sınırlar ve verilen cevaplardaki sapmalar göz önüne alınarak tehlike kategorileri için değer aralıkları tanımlanmıştır. Bu aralıklar Tablo 1'de verilmiştir.

Buna göre Etkilenme Derecesi "1" çıkması, ağrının yaşanma sıklığı, ağrının şiddeti ve ağrının işle ilgisi için verilen cevapların üçünün de 1 olduğu, başka bir deyişle ilgili vücut bölümünde herhangi bir sağlık sorunu yaşanmadığ bölümünde ağrının yaşanma sıklığına verdikleri cevaplara ait puanının "2" (2: haftada 1-2 defa) olmas1 durumunda, Etkilenme Derecesi üç faktöre (ağrının yaşanma sıklığı, ağrının şiddeti ve ağrının işle ilgisi) verilen " 2 " puanlarının çarpılması ile $2^{3}=8$ çıkacaktır. Ancak, cevapların 1 ve 2 puan arasında farkliliklar göstermesi durumunda bu cevap 2-7 arasında yer alacaktır. $\mathrm{Bu}$ aralık, anlamlı sonucun görüldüğü ilk aralık değeridir. Dolayısıyla Etkilenme Derecesi için hesaplanan 1 değeri "Anlamsız" olarak tanımlanırken, 2-7 aralığı "Düşük Düzey Tehlike" olarak tanımlanmıştır. Benzer şekilde 8-26 aralığ1 "Orta Düzey Tehlike", 27- 63 aralığ1 "Yüksek Düzey Tehlike", 64-125 aralığ1 "Çok Yüksek Düzey Tehlike" olarak tanımlanmıştır. Aralıkların standartlaştırılması ve önerilen yeni RDMMY'nin uygulanabilir hale getirilmesi amaciyla, aralıkların "Grup Puanı" adı verilen ve aralı̆̆ın puanını gösteren bir indisle puanlandırılması öngörülmüştür. Buna göre "Anlamsız" olarak nitelendirilen bölüm için "Grup Puanı" 1, "Düşük Düzey Tehlike" için "Grup Puanı" 2, "Orta Düzey Tehlike" olarak nitelendirilen bölüm için
"Grup Puanı" 3, "Yüksek Düzey Tehlike" olarak nitelendirilen bölüm için "Grup Puani" 4 ve son olarak "Çok Yüksek Düzey Tehlike" olarak nitelendirilen bölüm için "Grup Puanı" 5 olarak tanımlanmıştır.

Tehlikenin boyutu "Etkilenme Derecesi" ile hesaplanmakla birlikte bir diğer önemli faktör ise etkilenen kişi sayısıdır. $\mathrm{Bu}$ çalışmada yapılan uygulamada olduğu gibi, 43 kişinin ankete katıldığ 1 ve bunlardan sadece 1 kişinin belirli bir bölgede çok şiddetli ağrı hissettiğini, bu ağrının haftada 3-4 defa tekrarlandığını ve ağrının kesinlikle işle ilgili olduğunu belirttiğini göz önüne alırsak, etkilenme derecesi bu birey için yaklaşık olarak $3 \times 5 \times 5=75$ yani "Çok Yüksek Düzey Tehlike" sınıfındadır. Ancak tüm katılımcılar içinde sadece bir birey bunu belirtmiş, buna karşın ankete katılan diğer katılımcılar ilgili vücut bölümünde kayda değer bir rahatsızlık hissetmemişse; bu durumda bu tehlikenin genel bir tehlike olmadığı sonucuna varılır. Bu nedenle, elde edilen 75 puanın etkilenen kişi yoğunluğu ile çarpılması gerekir. İş sağlığ 1 ve güvenliğinde tehlikelerden korunmada öncelik sırası (i) tehlikeyi ortadan kaldır, (ii) tehlike tamamen ortadan kalkmiyorsa daha az tehlikeli olanla değiştir (ikame), (iii) tehlike halen devam ediyorsa tehlikenin yayılmasını engelle (kaynakta korunma uygulama), (iv) tehlikenin ortamda yayılmasını engelle, (v) kişilere kişisel koruyucu donanım dağıt şeklindedir. Tüm bu hiyerarşi içinde her zaman tehlikeden etkilenen kişi sayısı bir risk bileşeni olarak görülür ve mümkün olduğunca az kişinin tehlikeye maruz kalması beklenir. Dolayısıyla anket sonuçlarının yorumlanması amacıyla önerilen RDMMY'de etkilenen kişi sayısını da dahil etmek, tehlike sınıflandırmasının ve en çok etkilenen vücut bölümlerinin "öncelikle toplu koruma mantığg” içerisinde daha sağl1klı değerlendirilebilmesi için önemlidir.

Ankete katılanlardan ilgili vücut bölümünde rahatsızlık duyanların, toplam katılımcı sayısına oranlanması ile etkilenen kişi sayısına ilişkin bir çarpan değeri hesaplanmış ve Tablo 2'de verilmiştir.

Tablo 2. Etkilenen kişi yoğunluğu değerlendirme kriterleri (Assessment criteria for intensity of affected people)

\begin{tabular}{ll}
\hline Grup Puan1 & Aralık \\
\hline 1 & $\leq \% 20$ \\
2 & $\leq \% 40$ \\
3 & $\leq \% 60$ \\
4 & $\leq \% 80$ \\
5 & $\leq \% 100$ \\
\hline
\end{tabular}

Tablo 2'ye göre etkilenen kişi sayısının oranının tüm katılımcılar göz önüne alındığında \%20'ye eşit yada daha az olması durumunda "Grup Puanı” 1, \%40'a eşit yada daha az olması durumunda "Grup Puanı" 2 vb. şekilde tüm gruplar için bir çarpan değeri elde edilmiştir. Etkilenen kişi sayısı için bulunan Grup Puanı "Etkilenen Kişi Yoğunluğu" 
olarak isimlendirilmiştir. Son aşama, Risk Skorunu hesaplamak için Etkilenme Derecesi ile Etkilenen Kişi Yoğunluğu puanlarının birleştirilmesidir. Bu şekilde hem hissedilen ağrının büyüklüğü hem de bundan etkilenen kişi sayısı dikkate alınarak bir sınıflama yapılabilecektir. Risk skoru Eş. 2'de verildiği gibidir.

Risk Skoru=Etkilenme Derecesi $x$ Etkilenen Kişi Yoğunluğu(2)

Her bir vücut bölgesinde ağrı hisseden katılımcıların verdikleri cevaplar dikkate alınarak hesaplanan risk skorlarının Tablo 3'de verilen risk değerlendirme matrisinde hangi bölgede yer aldığı tespit edilerek, nihai risk değerlendirmesi yapılmaktadır.

Tablo 3. Risk Değerlendirme Matrisi (Risk Assessment Matrix)

\begin{tabular}{|c|c|c|c|c|c|c|}
\hline \multirow{7}{*}{ 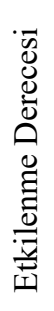 } & \multicolumn{6}{|c|}{ Etkilenen Kişi Yoğunluğu } \\
\hline & & 1 & 2 & 3 & 4 & 5 \\
\hline & 1 & 1 & 2 & 3 & 4 & 5 \\
\hline & 2 & 2 & 4 & 6 & 8 & 10 \\
\hline & 3 & 3 & 6 & 9 & 12 & 15 \\
\hline & 4 & 4 & 8 & 12 & 16 & 20 \\
\hline & 5 & 5 & 10 & 15 & 20 & 25 \\
\hline
\end{tabular}

Tablo 3'te verilen risk değerlendirme matrisine göre Risk Skoru 1,2,3,4 veya 5 değerlerinden biri olarak hesaplandiysa, bu sonuç tehlikenin Kabul Edilebilir Risk (Mavi) düzeyinde olduğunu ve bunun yanında Risk Skorunun 1 olarak hesaplanmas1 durumunda bu sonucun kabul edilebilir risk düzeyinde olmakla birlikte bir anlam ifade etmediği (Açık mavi) sonucuna varılmaktadır. Risk skorunun 6, 8 veya 9 bulunması Orta Düzey Risk (Sar1); 10 veya 12 hesaplanması Yüksek Düzey Risk (Turuncu); 15, 16,20 veya 25 hesaplanması durumunda ise Çok Yüksek Düzey Risk (Kırmızı) olduğu sonucuna varılmaktadır. Bu değerlendirme matrisinde risk bölgeleri belirlenirken; Etkilenme Derecesinin 3 (orta), Etkilenen Kişi Yoğunluğunun 3 (orta) ve risk skorunun ise $3 \times 3=9$ olduğu nokta orta düzey tehlike için referans sınır kabul edilmiştir. $\mathrm{Bu}$ noktanın üstü yüksek ve çok yüksek risk bölgesini oluştururken; altı ise orta düzey ve kabul edilebilir risk olarak tanımlanmıştır. Orta düzey risk skorunun alt sınır değerini (kabul edilebilir risk bölgesi için üst sınır) belirlemek için 5 sayısının asal sayı olma özelliği kullanılmıştır. Buna göre, risk skoru hesaplarken çarpımın 5 çıkması ancak ve ancak etkilenme derecesi 5 iken, etkilenen kişi yoğunluğunun 1 veya etkilenme derecesi 1 iken, etkilenen kişi yoğunluğunun 5 olması ile mümkündür. $\mathrm{Bu}$ nedenle risk skoru için 5 değeri kabul edilebilir risk bölgesi için üst sınır kabul edilmiştir. Etkilenme derecesi en az 3 iken etkilenen kişi yoğunluğunun 5 veya etkilenme derecesi 5 iken etkilenen kişi yoğunluğunun en az 3 olması; veya her iki bileşeninde orta derece puan olan 3 değerinin üzerinde olması ile hesaplanan risk skoru yüksek düzey risk olarak kabul edilmektedir. Risk skorunun 25 olarak hesaplanmas ise ancak ve ancak her iki risk skoru bileşenininde 5 olması ile mümkündür ki bu en yüksek risk değerini temsil eder.
Farklı bileşen değerleri için Eş.(2) ve Tablo 3'te önerilen $\mathrm{Kabul} /$ Red bölgelerinin test edilmesi gerekir. $\mathrm{Bu}$ amaçla aşağıda Tablo 4'de verilen denemeler gerçekleştirilmiştir. $\mathrm{Bu}$ denemelerle, önerilen risk değerlendirmesi matrisinde "kabul edilebilir" çıkan bir riskin aslında işyeri için yüksek risk grubunda olma durumu araştırılarak yöntemin geçerliliği doğrulanmaya çalışılmıştır. Deneme kombinasyonlarını belirlemek için ağrının şiddeti en az 2 ve etkilenen kişi yoğunluğu en az 2 (\%20'den büyük), diğer bileşenler ise 1-5 arasında olacak şekilde 400 farklı kombinasyonun risk skorları hesaplanmıştır. Bu risk skorları arasından risk skoru 5 ve 5 'in altında çıkanlar, başka bir deyişle önerilen yöntemin Tablo 3'de verilen risk değerlendirme matrisine göre kabul bölgesinde çıkanlar kayıt altına alınmıştır. $\mathrm{Bu}$ skor değerlerinde ağrının şiddetinin en az 2 değerinden başlıyor olması nedeniyle etkilenme derecesi için grup indisi her zaman 2'nin üzerinde olacaktır (minimum etkilenme derecesi skoru: $2 \times 1 \times 1=2)$. Önerilen RDMMY yöntemi toplu korumaya yönelik bir yöntem olup etkilenen kişi yoğunluğunun en az 2 (etkilenen kişi yoğunluğu \%20-40) olduğu durumlar göz önüne alındığında Risk Skoru en az 4 en çok 25 çıkacaktır. Hesaplanan bu değerler arasından, "kabul edilebilir" çıkan bir riskin aslında işyeri için yüksek risk grubunda olma ihtimaline karşı; Risk Skoru 5 değerinin altında olan, başka bir deyişle kabul edilebilir risk bölgesinde olan bileşen kombinasyonları incelenmiştir. Tablo 4'deki sonuçlar incelendiğinde etkilenen kişi yoğunluğu için skor değerinin 2 olduğu (\%20-40 arasında) gözlenmiştir. Çünkü "2" değerinin üzerinde bir yoğunluk olması durumunda ise diğer bileşenlerin değeri düşük olduğu durumda bile şiddet değerinin her zaman 2 ve 2 'nin üzerinde olacağ1 kabulü yapıldığı için; Risk Skoru Kabul edilebilir bölge dışında olacaktır.

Tablo 4'te verilen sonuçlar incelendiğinde, sonuçların tutarlı olduğu ve önerilen risk değerlendirmesi matrisinde "kabul edilebilir" çıkan bir riskin aslında işyeri için yüksek risk grubunda bulunma durumunun olmadığ1 görülmüştür. Tablo 4'te Ağrının Yaşanma Siklı̆̆l (Frekans), A ğrının Şiddeti, A ̈̆rının Işsle İlgisi ile ilgili sorulardan en az birinin ortalamasının 1 olduğu görülmüştür. Ancak değerlendirmelerde yöntem gereği 1 puan verilen cevaplar etkilenme derecesi hesabına dahil edilmediğinden dolayı her hâlükârda, Tabloda verilen etkilenme derecelerinden daha büyük değerler elde edilecektir. $\mathrm{Bu}$ da etkilenme derecesi için grup puanının ya aynı kalmasına ya da artmasina, dolayısıyla risk skorunun ya aynı kalmasina veya artmasına sebep olacaktır. Risk skorunun artması da, belirtilen vücut bölümü için riskin kabul edilebilir sınırlardan, önlem alınması gereken bölgelere doğru kayması anlamına gelir. Mevcut durumda bile en fazla 10 kombinasyon risk değerlendirme matrisinde kabul edilebilir risk bölgesinde kalmakta iken, bu değerler ancak ankete katılan katılımcıların tamamının belirli bir vücut bölgesi için anketin bir bölümüne tamamen 1 puan vermesi ile mümkün olabilir. Sonraki bölümde, önerilen RDMMY'nin test edildiği üretim sistemi, elde edilen sonuçlar ve doğrulaması verilmiştir. 
Tablo 4. RDMMY Test sonuçları (Test results for MMMRA)

\begin{tabular}{|c|c|c|c|c|c|c|c|c|c|}
\hline \multirow[b]{2}{*}{ 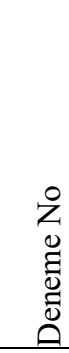 } & \multicolumn{3}{|c|}{$\begin{array}{l}\text { Etkilenme } \\
\text { Derecesi }\end{array}$} & \multirow[b]{2}{*}{ 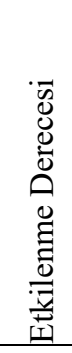 } & \multirow{2}{*}{ 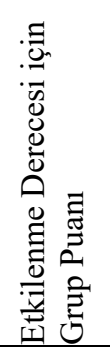 } & \multirow[b]{2}{*}{ 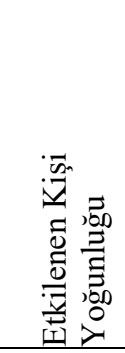 } & \multirow[b]{2}{*}{ 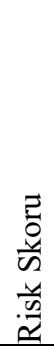 } & \multirow[b]{2}{*}{$\begin{array}{l}\text { Risk } \\
\text { Derecesi }\end{array}$} & \multirow[b]{2}{*}{ Yorum } \\
\hline & 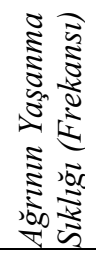 & 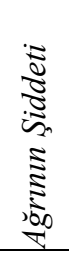 & 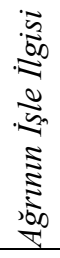 & & & & & & \\
\hline 1 & 1 & 2 & 1 & 2 & 2 & 2 & 4 & $\begin{array}{l}\text { Kabul } \\
\text { Edilebilir } \\
\text { Risk }\end{array}$ & $\begin{array}{l}\text { Ağrının sıklığı: son } 1 \text { haftada hiç } \\
\text { olmadı; Şiddet değeri: az; } \\
\text { Ağrının işle ilgisi: çok az; } \\
\text { Sonuç: risk derecelendirmesi tutarlı. }\end{array}$ \\
\hline 2 & 1 & 2 & 2 & 4 & 2 & 2 & 4 & $\begin{array}{l}\text { Kabul } \\
\text { Edilebilir } \\
\text { Risk }\end{array}$ & $\begin{array}{l}\text { Ağrının sıklı̆̆ı: son } 1 \text { haftada hiç } \\
\text { olmadı; Şiddet değeri: az; } \\
\text { Ağrının işle ilgisi: az; } \\
\text { Sonuç: risk derecelendirmesi tutarlı. }\end{array}$ \\
\hline 3 & 1 & 2 & 3 & 6 & 2 & 2 & 4 & $\begin{array}{l}\text { Kabul } \\
\text { Edilebilir } \\
\text { Risk }\end{array}$ & $\begin{array}{l}\text { Ağrının sıklığı: son } 1 \text { haftada hiç } \\
\text { olmadı; Şiddet değeri: az; } \\
\text { Ağrının işle ilgisi: orta derece; } \\
\text { Sonuç: risk derecelendirmesi tutarlı. }\end{array}$ \\
\hline 4 & 1 & 3 & 1 & 3 & 2 & 2 & 4 & $\begin{array}{l}\text { Kabul } \\
\text { Edilebilir } \\
\text { Risk }\end{array}$ & $\begin{array}{l}\text { Ağrının sıklığı: son } 1 \text { haftada hiç } \\
\text { olmadı; Şiddet değeri: orta derece; } \\
\text { Ağrının işle ilgisi: çok az; } \\
\text { Sonuç: risk derecelendirmesi tutarlı. }\end{array}$ \\
\hline 5 & 1 & 3 & 2 & 6 & 2 & 2 & 4 & $\begin{array}{l}\text { Kabul } \\
\text { Edilebilir } \\
\text { Risk }\end{array}$ & $\begin{array}{l}\text { Ağrının sıklı̆̆ı: son } 1 \text { haftada hiç } \\
\text { olmadı; Şiddet değeri: orta derece; } \\
\text { Ağrının işle ilgisi: az; } \\
\text { Sonuç: risk derecelendirmesi tutarlı. }\end{array}$ \\
\hline 6 & 1 & 4 & 1 & 4 & 2 & 2 & 4 & $\begin{array}{l}\text { Kabul } \\
\text { Edilebilir } \\
\text { Risk }\end{array}$ & $\begin{array}{l}\text { Ağrının sıklı̆̆ı: son } 1 \text { haftada hiç } \\
\text { olmadı; Şiddet değeri: fazla; } \\
\text { Ağrının işle ilgisi: çok az; } \\
\text { Sonuç: risk derecelendirmesi tutarlı. }\end{array}$ \\
\hline 7 & 1 & 5 & 1 & 5 & 2 & 2 & 4 & $\begin{array}{l}\text { Kabul } \\
\text { Edilebilir } \\
\text { Risk }\end{array}$ & $\begin{array}{l}\text { Ağrının sıklı̆̆ı: son } 1 \text { haftada hiç } \\
\text { olmadı; Şiddet değeri: çok fazla; } \\
\text { Ağrının işle ilgisi: çok az; } \\
\text { Sonuç: risk derecelendirmesi tutarlı. }\end{array}$ \\
\hline 8 & 2 & 2 & 1 & 4 & 2 & 2 & 4 & $\begin{array}{l}\text { Kabul } \\
\text { Edilebilir } \\
\text { Risk }\end{array}$ & $\begin{array}{l}\text { Ağrının sıklığı: son } 1 \text { haftada 1-2 } \\
\text { defa; } \\
\text { Şiddet değeri: az; } \\
\text { Ağrının işle ilgisi: çok az; } \\
\text { Sonuç: risk derecelendirmesi tutarlı. }\end{array}$ \\
\hline 9 & 2 & 3 & 1 & 6 & 2 & 2 & 4 & $\begin{array}{l}\text { Kabul } \\
\text { Edilebilir } \\
\text { Risk }\end{array}$ & $\begin{array}{l}\text { Ağrının sıklığı: son } 1 \text { haftada 1-2 } \\
\text { defa; } \\
\text { Şiddet değeri: orta derece; } \\
\text { Ağrının işle ilgisi: çok az; } \\
\text { Sonuç: risk derecelendirmesi tutarlı. }\end{array}$ \\
\hline 10 & 3 & 2 & 1 & 6 & 2 & 2 & 4 & $\begin{array}{l}\text { Kabul } \\
\text { Edilebilir } \\
\text { Risk }\end{array}$ & $\begin{array}{l}\text { Ağrının sıklığı: son } 1 \text { haftada 3-4 } \\
\text { defa; } \\
\text { Şiddet değeri: az; } \\
\text { Ağrının işle ilgisi: çok az; } \\
\text { Sonuç: risk derecelendirmesi tutarlı. }\end{array}$ \\
\hline
\end{tabular}




\section{UYGULAMA (APPLICATION)}

\subsection{Sistemin Tanımı (Description of the System)}

Nursan Kablo Donanımları Sanayi ve Ticaret Anonim Şirketi, Tavşanlı Organize Sanayi Bölgesinde $60.000 \mathrm{~m}^{2}$ 'lik bir arazi üzerinde kurulmuş, 2000 kişiyi bulan çalışanı ve geniş makine parkıyla binek, ticari ve kamyon gibi taşıt araçlarının elektrik donanımlarını ve akü kablolarını üreten bir otomotiv yan sanayi kuruluşudur. Şekil 2'de üretim sisteminin genel görünümü verilmiştir.

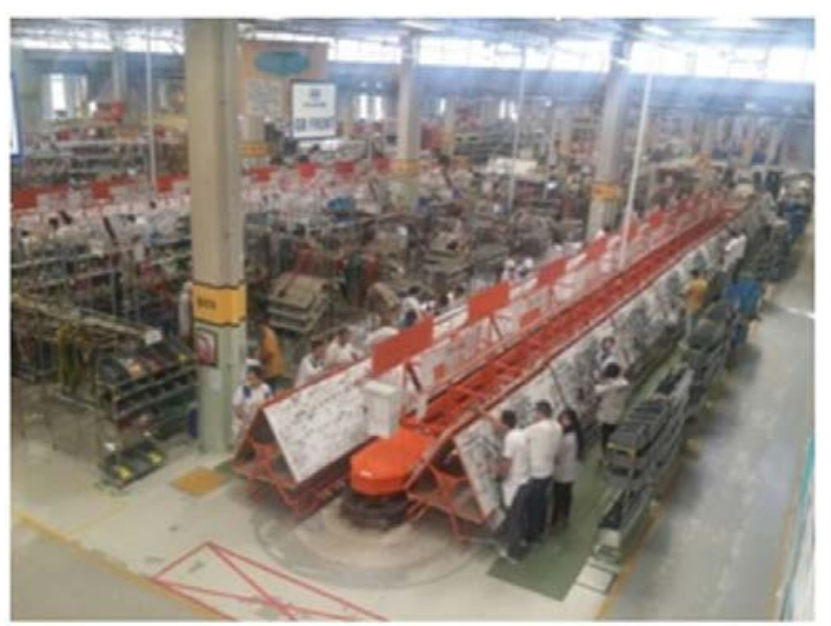

Şekil 2. Üretim sisteminin genel görünümü (Overview of the production system)

Kablo demetleme konveyör hatlarında gerçekleştirilen kablo demetleme işleminde çalışan işgörenin bu işlemleri gerçekleştirirken uzun süre ayakta kalması, boyu uzun işgörenin eğilerek, boyu kısa işgörenin uzanarak çalışması v.b. çalışma pozisyonları yorulmalara ve zorlanmalara neden olmaktadır. Bu durum çalışanlarda zamanla meslek hastalıklarından birisi olan KİSR olasılığını artırmaktadır. Aynı zamanda ergonomik açıdan uygun olmayan çalışma pozisyonu işgörenin iş performansını da etkilemektedir. Uygulama yapılan firma tarafından üretim hattında KİSR'dan kaynaklı üretim kayıplarının azaltılarak, günlük üretim miktarının arttırılması için iş istasyonlarının ergonomik olarak yeniden tasarlanması istenmektedir. Yeniden tasarım aşamasında; ergonomik hat tasarımı yapabilmek amaciyla, farklı fiziksel özelliklere sahip çalışanların geneline hitap edecek şekilde hangi vücut bölümlerinin dikkate alınması gerektiğine karar verebilmek için önerilen RDMMY yönteminden faydalanılmıştır. Çalışma esnasında sıklıkla gözlenen duruş bozukluklarına ait örnekler Şekil 3'te verilmiştir. Çalışanlar birbirine göre oldukça farklı antropometrik özelliklere sahiptir. Hat çalışanlarının antropometrik ölçümleri (montaj sehpa yüksekliği için çalışanların boy uzunlukları, omuzbaşı, dirsek ve bilek yükseklikleri, kablo sarma veya yerleştirme işlemleri için öne doğru erişme uzaklıkları) alındığında, kadınların boy uzunluklarının $161 \mathrm{~cm}$ ile $165 \mathrm{~cm}$ arasında, erkeklerin boy uzunluklarının $163 \mathrm{~cm}$ ile $181 \mathrm{~cm}$ arasında değiştiği görülmüştür. Pano yüksekliği $150 \mathrm{~cm}$ 'dir. Panonun üst kısmında ya da alt kısmında çalış1lırken çalışanların yukarıya doğru uzanmaları ya da aşağıya doğru eğilmeleri gerekmektedir. Gün içerisinde tekrarlı olarak yapılan bu hareketler çalışanlarda zorlanmalara neden olmaktadır. Bu çalışmada amaç; mevcut montaj hattından kaynaklı olarak çalışanların özellikle hangi vücut bölümlerinde şikayet oluştuğu; bu şikayetlerin sıklığı, şiddeti ve işle ilgisinin tespit edilerek, yeni montaj hattı tasarlanırken hangi bölgelerin özellikle dikkate alınması gerektiğinin RDMMY yöntemi ile belirlenmesidir.

\subsection{RDMMY ile Elde Edilen Sonuçlar}

(The Results Obtained with MMMRA)

Seçilen mevcut montaj hattındaki çalışanların yeni tasarlanacak montaj hattında da çalışacağı öngörüldüğü için anket çalışması, mevcut montaj hattındaki 43 çalışana uygulanmıştır. Yapılan çalışmada Cornell Üniversitesinin "Kas İskelet Sistemi Rahatsızlık Anketi”çalışma amacına uygun şekilde modifiye edilerek uyarlanmıştır ve anket yanıtlarının tutarlılı̆̆ 1 için güvenirlik analizi yapılmıştır. Minitab 17'de gerçekleştirilen güvenirlik analizi sonucu tüm anket için Cronbach Alpha değeri 0,8791 olarak elde edilmiştir. $\mathrm{Bu}$ sonuca göre anketin toplam güvenirliği yüksektir. Her sorunun güvenirlik katsayısı ayrı ayrı da değerlendirilmiş ve herhangi bir anket sorusunun çıkarılmasıyla toplam anket güvenirliğinin önemli derecede yükselmediği tespit edilmiştir. Bu nedenle anketteki tüm sorular değerlendirmeye alınmıştır. Anket, hedef ana kütlenin tamamına uygulandığı için tam sayımdır ve bu nedenle anketin geçerliliği ve ana kütleye genelleştirilmesi ile ilgili istatistiksel analizler söz konusu değildir. Ankete tam sayım yoluyla katılan katılımcilara ait hesaplamalar Tablo 5'te verilmiştir. Tabloda verilen A, B, C ile

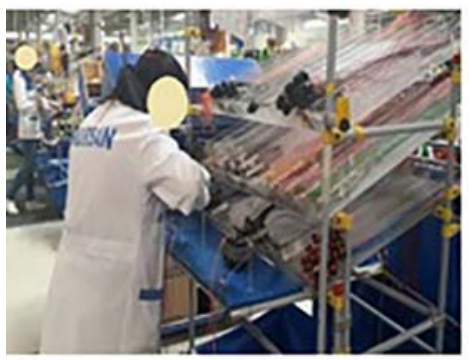

a) Ön hazırlık aşaması (a) (Preparation phase

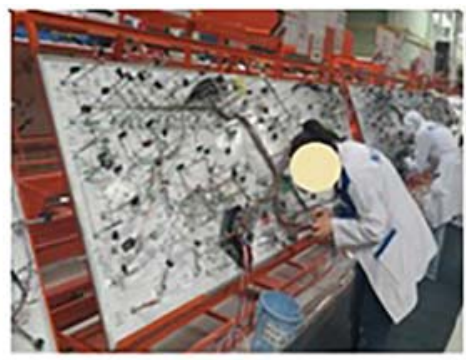

b) Kablo döşeme aşaması (b) (Wiring phase)

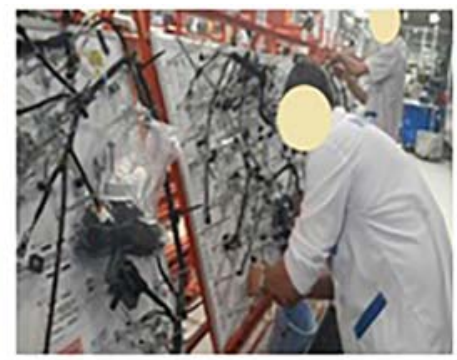

c) Bantlama ve aksesuar takma aşamas (c) (Banding and installing accessories phase)

Şekil 3. Çalışma ortamında gözlenen duruş bozuklukları (Observed postures in the working environment) 
Tablo 5. Özet tablo (Summary table)

\begin{tabular}{|c|c|c|c|c|c|c|c|c|c|c|}
\hline AÇIKLAMA** & $\mathrm{A}$ & $\mathrm{B}$ & $\mathrm{C}$ & $\mathrm{D}$ & $\mathrm{E}$ & $\mathrm{F}$ & $\mathrm{G}$ & $\mathrm{H}$ & $\mathrm{I}$ & Renk \\
\hline BOYUN & 2,8 & 2,8 & 2,9 & 0,6 & 3 & 23 & 3 & 9 & Orta & (Sar1) \\
\hline OMUZ (SOL) & 3,2 & 2,9 & 2,6 & 0,5 & 3 & 24 & 3 & 9 & Orta & (Sar1) \\
\hline OMUZ (SAĞ) & 3,3 & 2,9 & 2,7 & 0,5 & 3 & 26 & 3 & 9 & Orta & (Sar1) \\
\hline SIRT & 3,7 & 2,8 & 2,8 & 0,4 & 2 & 29 & 4 & 8 & Orta & (Sar1) \\
\hline ÜST KOL -PAZU (SOL) & 3,8 & 3,4 & 3,3 & 0,2 & 1 & 42 & 4 & 4 & Düşük & (Mavi) \\
\hline ÜST KOL -PAZU (SAĞ) & 3,9 & 3,4 & 3,6 & 0,2 & 1 & 48 & 4 & 4 & Düşük & (Mavi) \\
\hline BEL & 3,2 & 2,9 & 2,9 & 0,4 & 2 & 26 & 3 & 6 & Orta & (Sar1) \\
\hline ÖN KOL (SOL) & 3,3 & 3 & 2,7 & 0,2 & 1 & 26 & 3 & 3 & Düşük & (Mavi) \\
\hline ÖN KOL (SAĞ) & 3,5 & 3 & 3,2 & 0,1 & 1 & 34 & 4 & 4 & Düşük & (Mavi) \\
\hline DİRSEK (SOL) & 3,3 & 3,7 & 2 & 0,1 & 1 & 24 & 3 & 3 & Düşük & (Mavi) \\
\hline DİRSEK (SAĞ) & 3 & 4 & 2 & 0,1 & 1 & 24 & 3 & 3 & Düşük & (Mavi) \\
\hline BİLEK -EL (SOL) & 3,9 & 3,6 & 3,4 & 0,2 & 1 & 48 & 4 & 4 & Düşük & (Mavi) \\
\hline BİLEK -EL (SAĞ) & 4,1 & 3,2 & 3,6 & 0,2 & 1 & 48 & 4 & 4 & Düşük & (Mavi) \\
\hline KALÇA & 3,6 & 3,2 & 2,9 & 0,2 & 1 & 33 & 4 & 4 & Düşük & (Mavi) \\
\hline UYLUK (SOL) & 3,5 & 3,2 & 3 & 0,1 & 1 & 33 & 4 & 4 & Düşük & (Mavi) \\
\hline UYLUK (SAĞ) & 3 & 3,4 & 3,3 & 0,1 & 1 & 34 & 4 & 4 & Düşük & (Mavi) \\
\hline DİZ (SOL) & 3,4 & 3,7 & 3,1 & 0,2 & 1 & 39 & 4 & 4 & Düşük & (Mavi) \\
\hline DİZ (SAĞ) & 3,9 & 3,7 & 3,6 & 0,2 & 1 & 52 & 4 & 4 & Düşük & (Mavi) \\
\hline BALDIR (SOL) & 4,4 & 3,4 & 3,5 & 0,2 & 1 & 52 & 4 & 4 & Düşük & (Mavi) \\
\hline BALDIR (SAĞ) & 4 & 3,9 & 4,2 & 0,1 & 1 & 65 & 5 & 5 & Düşük & (Mavi) \\
\hline AYAK (SOL) & 4,4 & 3,9 & 4,2 & 0,4 & 2 & 72 & 5 & 10 & Yüksek & (Turuncu) \\
\hline AYAK (SAĞ) & 4,3 & 4,1 & 3,9 & 0,3 & 2 & 68 & 5 & 10 & Yüksek & (Turuncu) \\
\hline A BÖLGESİ (SOL) & 3,6 & 4,8 & 4,5 & 0,1 & 1 & 77 & 5 & 5 & Düşük & (Mavi) \\
\hline A BÖLGESİ (SAĞ) & 4 & 3,8 & 4,3 & 0,1 & 1 & 64 & 5 & 5 & Düşük & (Mavi) \\
\hline B BÖLGESİ (SOL) & 5 & 4 & 3,5 & 0 & 1 & 70 & 5 & 5 & Düşük & (Mavi) \\
\hline B BÖLGESİ (SAĞ) & 5 & 2 & 2 & 0 & 1 & 20 & 3 & 3 & Düşük & (Mavi) \\
\hline C BÖLGESİ (SOL) & 4 & 3 & 1 & 0 & 1 & 12 & 3 & 3 & Düşük & (Mavi) \\
\hline C BÖLGESİ (SAĞ) & 3 & 1 & 1 & 0 & 1 & 3 & 2 & 2 & Düşük & (Mavi) \\
\hline D BÖLGESİ (SOL) & 3 & 1 & 2 & 0 & 1 & 6 & 2 & 2 & Düşük & (Mavi) \\
\hline D BÖLGESİ (SAĞ) & 2 & 1 & 3 & 0 & 1 & 6 & 2 & 2 & Düşük & (Mavi) \\
\hline E BÖLGESİ (SOL) & 2 & 5 & 4 & 0 & 1 & 40 & 4 & 4 & Düşük & (Mavi) \\
\hline E BÖLGESİ (SAĞ) & 3 & 5 & 5 & 0 & 1 & 75 & 5 & 5 & Düşük & (Mavi) \\
\hline F BÖLGESİ (SOL) & 3 & 5 & 5 & 0 & 1 & 75 & 5 & 5 & Düşük & (Mavi) \\
\hline F BÖLGESİ (SAĞ) & 1 & 5 & 5 & 0 & 1 & 25 & 1 & 1 & Düşük & (Mavi) \\
\hline $\begin{array}{l}\text { **A: Anket 1. Bölümüne ait orta } \\
\text { B: Anket 2. Bölümüne ait ortalan } \\
\text { C: Anket 3. Bölümüne ait ortalan } \\
\text { D: Etkilenen kişi yoğunluğu (\%) }\end{array}$ & & & G: & leriा & & $\begin{array}{l}\text { i (Ta } \\
\text { a için }\end{array}$ & 1) & 014 & $\begin{array}{l}\text { pindisi (T } \\
\text { Risk Düze, } \\
\text { G) }\end{array}$ & \\
\hline
\end{tabular}

isimlendirilen sütunlar sırasıyla; satırlar bazında verilen her bir vücut bölümü için Ağrının Yaşanma Sıklı̆̆l (Frekans), Ăgrının Şiddeti, Ăgrının İşle İlgisi ile ilgili sorulara katılımcıların verdiği cevapların aritmetik ortalamalarını göstermektedir. $\mathrm{Bu}$ aritmetik ortalamalar hesaplanırken önerilen RDMMY'nin hesap sistemi gereği (bkz. Bölüm 2), ankete katılanlar tarafindan "1" puan verilen cevaplar dikkate alınmamış, sadece "1" puanın üzerindeki cevaplar dikkate alınmıştır. Bu üç bileşenin Eş.1'de verildiği gibi çarpılması ile Etkilenme Derecesi hesaplanmaktadır. Etkilenme derecesi için hesaplanan ham puanlar $F$ sütununda verilmiştir. F sütununda hesaplanan ham puanların, yöntem gereği Tablo 1 kullanılarak 1-5 arasında bir değere çevrilmesi gerekmektedir. Bu yeni değerler $\mathrm{G}$ sütununda verilmiştir. Buraya kadar Etkilenme Derecesinin nasıl hesaplandığ 1 Tablo 5 üzerinden anlatılmıştır. Risk skoru Eş.2'de verildiği gibi Etkilenme derecesi ile Etkilenen kişi yoğunluğunun çarpılması ile bulunmaktadır. Etkilenen 432 kişi yoğunluğu ise ankete katılanlardan ilgili vücut bölümünde rahatsızlık duyanların, toplam katılımcı sayısına oranlanması ile hesaplanmaktadır. Her bir vücut bölümü için etkilenen kişi yoğunluğu oransal olarak D sütununda verilmiştir. D sütununda verilen ham değerlerin, Etkilenme derecesi puanı hesabında olduğu gibi yöntem gereği 1-5 arasında bir grup puanına çevrilmesi gerekmektedir. Bu çevrim Tablo 2 kullanılarak yapılan dönüştürmenin sonucu, E sütununda yer almaktadır. Son işlem ise $E$ ve $G$ sütunlarında hesaplanan puanların çarpılması ile elde edilen Risk Skorlarının (H sütunu), Tablo 3'de verilen risk değerlendirme matrisinde hangi bölgeye düştüğünün belirlenmesi işlemidir. RDMMY'nin işleyişi, Tablo 5'de 2. sütunda verilen "Boyun" bölgesi için adım adım aşağıdaki gibidir:

Adım 1: A sütunu hesabı: Şekil 1'de bölümleri verilen anket formunun 1. Bölümünde sorulan "Geçtiğimiz hafta 
içinde belirtilen vücut bölgesi ile ilgili hangi sıkl1kta acı, ağrı veya rahatsızlık deneyiminiz oldu" sorusuna, 43 katılımcidan 25'i, 2 (Haftada 1-2 defa) - 5 (Günde birkaç defa) arasında bir puan vermiştir. 18 kişi ise 1 puan vererek hiç ağrı hissi yaşamadığını belirtmiştir. Farklı derecelerde ağrı yaşayan 25 katılımcının Boyun bölgesi için vermiş olduğu 2-5 arasındaki puanların ortalaması 2,8'dir. Bu değer Eş.1'de Etkilenme Derecesi hesabında çarpan olarak kullanılan Ăgrının Yaşanma Sıklı̆̆ (Frekans) değeridir. Bu adımda hesaplanan 2,8 frekans değeri Adım 6'da Etkilenme Derecesi hesabında kullanılacaktır.

Adım 2: B sütunu hesabı: Anket formunun 2. Bölümünde sorulan "Eğer böyle bir deneyiminiz olduysa, bu rahatsızlığınızı derecelendirin" sorusuna, 43 katılımcıdan 23'ü, 2 (Az) - 5 (Çok fazla) arasında bir puan vermiştir. 20 kişi ise 1 puan (Çok az) vererek çok az bir ağrı hissi yaşadığını belirtmiştir. 2-5 arasında puan veren 23 katılımcının Boyun bölgesi için vermiş olduğu puanların ortalaması 2,8'dir. Bu değer Eş.1'de etkilenme derecesi hesabında çarpan olarak kullanılan A ğrının Şiddeti değeridir. $\mathrm{Bu}$ adımda hesaplanan 2,8 ağrı şiddeti değeri Adım 6'da Etkilenme Derecesi hesabında kullanılacaktır.

Adım 3: C sütunu hesabı: Anket formunun 3. Bölümünde sorulan "Eğer böyle bir deneyiminiz olduysa, bu rahatsızlığın yaptığınız işle ilgisini derecelendirin" sorusuna, 43 katılımcıdan 19'u, 2 (Az) - 5 (Çok fazla) arasında bir puan vermiştir. 24 kişi ise 1 puan (Çok az) vererek ağrısının yaptığı işten ziyade farklı özel sağlık sorunlarından kaynaklandığını belirtmiştir. 2-5 arasında puan veren 19 katılımcının Boyun bölgesi için vermiş olduğu puanların ortalaması 2,9'dur. Bu değer Eş.1'de etkilenme derecesi hesabında çarpan olarak kullanılan Ăgrının İşle İlgisi değeridir. Bu adımda hesaplanan 2,9 değeri Adım 6'da Etkilenme Derecesi hesabında kullanılacaktır.

Adım 4: D sütunu hesabı: Anket formunun 1. Bölümünde sorulan "Geçtiğimiz hafta içinde belirtilen vücut bölgesi ile ilgili hangi sıklıkta acı, ağrı veya rahatsızlık deneyiminiz oldu" sorusuna 1 puan haricinde puan veren katilımciların sayısının toplam katılımciların sayısına oranlanması ile Etkilenen kişi yoğunluğuna ait oran bulunur. 43 katılımcıdan 25'i Boyun bölgesinde ağrı yaşayıp yaşamamasına ilişkin olarak, 2 (Haftada 1-2 defa) - 5 (Günde birkaç defa) arasında bir puan vermiştir. 18 kişi ise 1 puan vererek hiç ağrı hissi yaşamadığını belirtmiştir. Boyun bölgesi Risk Skoru hesabında kullanılacak olan Etkilenen Kişi Yoğunluğu için ham puan 25/43=0,58 olarak hesaplanmıştır. Bu değer daha sonra Adım 5'te Tablo 2'den yararlanılarak; Risk Skoru hesabinda kullanılan ve 1-5 arasında değer alan Etkilenen Kişi Yoğunluğu Grup Puanına dönüştürülecektir.

Adım 5: E sütunu hesabı:Adım 4'te D sütununda hesaplanan değerler, Adım 5'te Tablo 2'den yararlanılarak Etkilenen Kişi Yoğunluğu bileşenine dönüştürülmektedir. $\mathrm{Bu}$ risk skoru bileşeni 1-5 arasında değer almaktadır. Boyun bölgesi için hesaplanmış olan yaklaşık \%58'lik yoğunluk, Tablo 2'de verilen puan çevrimine göre "3” puana karşılık gelmektedir. $\mathrm{Bu}$ adımda Etkilenen Kişi Yoğunluğu için hesaplanan 3 skor değeri, Adım 6'da Etkilenme Derecesi hesabında kullanılacaktır.

Adım 6: F sütunu hesabı:Adım 1-3'de hesaplanan ham puanlar Eş.1'de verilen Etkilenme Derecesi=Ağrının Yaşanma Sikliğı (Frekansı)xAğrının ŞiddetixAğrının Iş̧le Illgisi formülüne göre çarpılarak etkilenme derecesi için ham puan hesaplanmaktadır. Boyun bölgesi için Etkilenme Derecesi $=2,8 \times 2,8 \times 2,9=22,74$ olarak hesaplanmıştır. $\mathrm{Bu}$ ham puan Adım 7'de Etkilenme derecesi için 1-5 arasında bir skor değerine dönüştürülecektir.

Adım 7: G sütunu hesabı:Adım 6'da hesaplanan ham puan, Tablo 1'den yararlanılarak Etkilenme Derecesi için 1-5 arasında bir skor değerine dönüştürülmektedir. Boyun bölgesi için etkilenme derecesinin skor değeri "3" olarak belirlenmiştir.

Adım 8: $H$ sütunu hesabı:Adım 5 E sütunu ve Adım 7 G sütunu hesabıyla ortaya çıkan skor değerleri; Eş.2'de verilen Risk Skoru=Etkilenme DerecesixEtkilenen Kişi Yoğunluğu formülüne göre çarpilarak $\mathrm{H}$ sütunu oluşturulmaktadır. Bu adımda hesaplanan Risk Skoru, Adım 9'da risk düzeyinin belirlenmesinde kullanılacaktır. Boyun bölgesi için Risk Skoru=3x3=9 olarak hesaplanmıştır.

Adım 9: I sütunu hesabı:Adım 9'da hesaplanan Risk skoru, Tablo 3'de verilen risk değerlendirme matrisine göre değerlendirilir ve kabul edilebilir veya kabul edilemez bir risk olup olmadığına bakılır. Boyun bölgesi için hesaplanan 9 risk skor değeri, risk değerlendirme matrisinde sarı ile gösterilen orta düzey risk sınıfında yer almaktadır. Bu adımlar ankette yer alan 34 farklı vücut bölümü için tekrarlanarak toplu korumaya yönelik alınacak önlemlerde öncelikle hangi vücut bölümlerinin dikkate alınması gerektiğine karar verilmiştir. Firmanın kurmayı hedeflediği ergonomik üretim hattının aynı anda tüm vücut bölümleri için ergonomik çalışmaya imkan vermesi mümkün olamayacağından dolayı, Bölüm 3'de verilen örnek çalışma ile hat tasarımında öncelikli göz önüne alınacak vücut bölümleri belirlenmiştir. Değerlendirme sonucunda ayaklarda yüksek düzey risk hesaplanmışken (turuncu bölge); boyun, omuz, sirt ve bel bölgelerinde orta düzey risk (sarı bölge) hesaplanmıştır. Diğer vücut bölgelerindeki risk düzeyi ise önerilen matris yöntemine göre kabul edilebilir sınırlar (mavi bölge) içerisinde yer almıştır.

\subsection{Doğrulama Testleri (Confirmation Tests)}

Kablo demetleme konveyör hattı çalışanlarının kas iskelet sistemi rahatsılıklarını değerlendirmek üzere yapılan anket çalışması sonuçların doğrulanması; gözleme dayalı REBA yöntemi ve eklemlerdeki yük değerlerini sayısal olarak hesaplayabilen AMS ile analiz edilmiştir. Ayrıca bu sonuçları değerlendirmek amacıyla çalışanlar üzerinde EMG ölçümleri gerçekleştirilmiştir. Hignett ve McAtamney 
[43] tarafından geliştirilen REBA; çalışanın çalışma pozisyonunu analiz ederek, mesleki kas ve iskelet sistemi rahatsızlıklarına neden olabilecek çalışma şeklinin saptanmasına ve önlem alınmasına olanak sağlayan gözleme dayalı bir duruş analiz metodudur. AMS, insan vücudunun istenilen büyüklükteki alt sistemlerini veya tüm insan vücudunu modellemek için kullanılabilen bir bilgisayar destekli modelleme ve analiz sistemidir [44]. EMG ise bir kasın, kas aktiviteleri hakkında biyoelektriksel bilgileri bünyesinde barındıran bir yöntemdir [45]. REBA analizleri, hat çalışanlarının farklı çalışma pozisyonları (Şekil 4) dikkate alınarak yapılmıştır. Risk değeri ifade edilirken farklı çalışma pozisyonları için yapılan analizler sonucundaki en yüksek değerler göz önünde bulundurulmuştur. REBA yöntemi ile ergonomik açıdan uygun olmayan çalışma pozisyonları değerlendirildiğinde; hat çalışanlarının eğilerek, uzanarak ve vücudu burarak çalıştıkları ve bu çalışma pozisyonlarında çalışanların gövde, boyun ve üst kollarında risk puanlarının yüksek olduğu görülmüştür (Tablo 6). REBA yönteminde çalışanların ayakları ile ilgili direkt bir hesaplama yoktur, bacaklar ile ilgili skor hesaplanırken iki ayağın üzerine basması ya da tek ayağın üzerine basması dikkate alınmaktadır. Yapılan REBA analizlerinde belirli bir gözlem süresi boyunca ergonomik olmayan anlık çalışma pozisyonları dikkate alınmaktadır. REBA yöntemi ile değerlendirilen çalışma pozisyonları içerisinde en çok zorlanmaların gözlendiği gövde ve ayaklar AMS ile de analiz edilmiştir (Şekil 5). Bu vücut bölümleri için AMS ile yapılan analizlerin özeti Tablo 7'de verilmiştir.

AMS analizinde öncelikle doğal duruş pozisyonunda (nötr duruş) ölçüm yapılmış, daha sonra çalışma esnasında ölçüm alınmıştır. Yapılan ölçüm sonuçları, çalışma yapılmayan doğal duruş ile karşılaştırıldığında L4-L5 omurlarında, omuzlarda (Glenohumeral) ve ayaklarda zorlanmaların
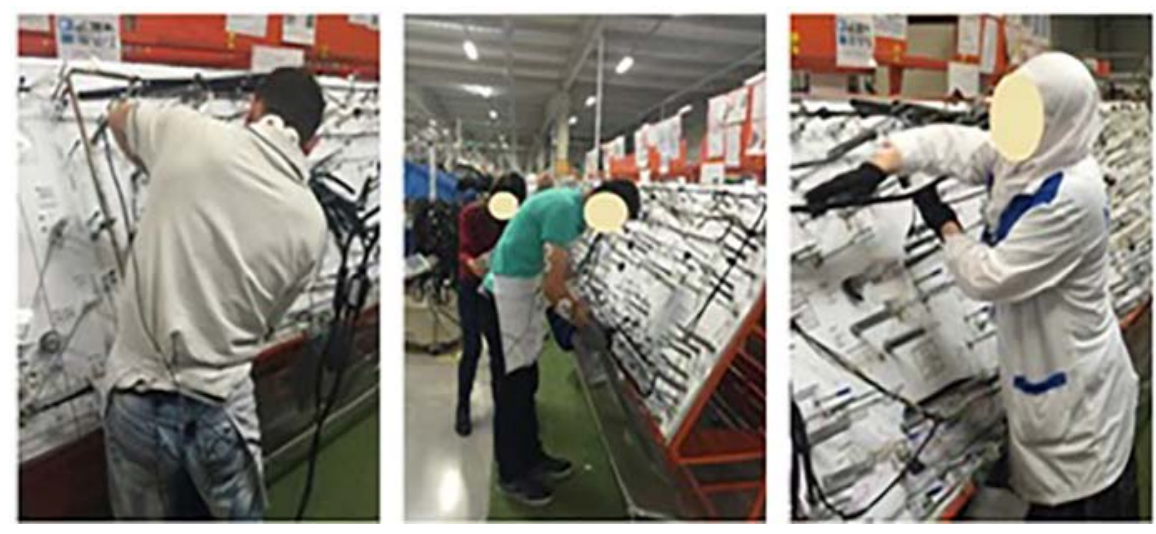

Şekil 4. REBA için örnek çalışma pozisyonu (Examples of working positions for REBA)
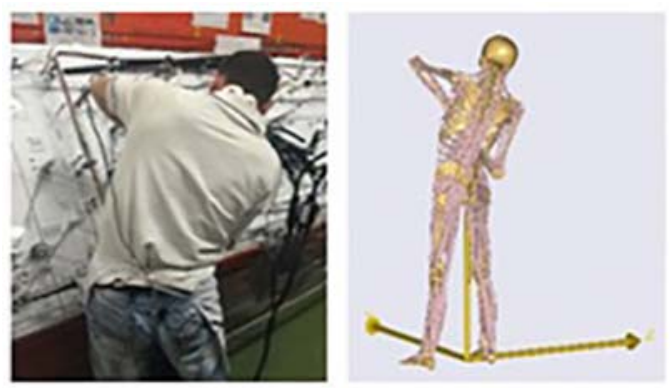

(a)

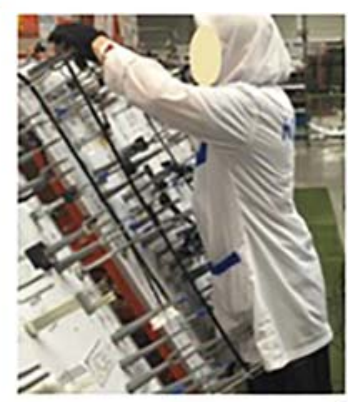

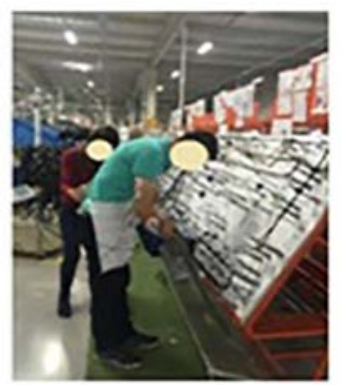

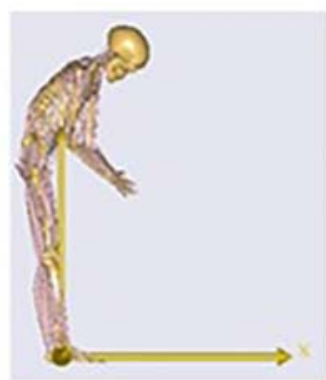

(b)

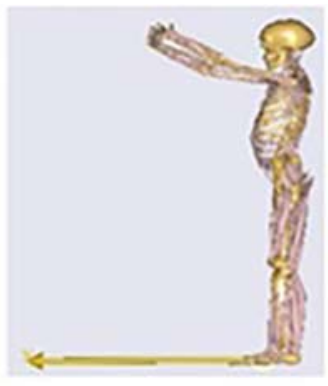

(c)

Şekil 5. AMS için örnek çalışma pozisyonları (Examples of working positions for AMS analysis) 


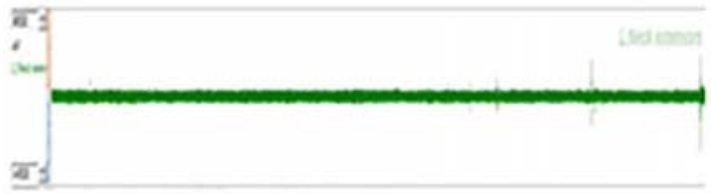

(a) Nötr durum (Neutral position)

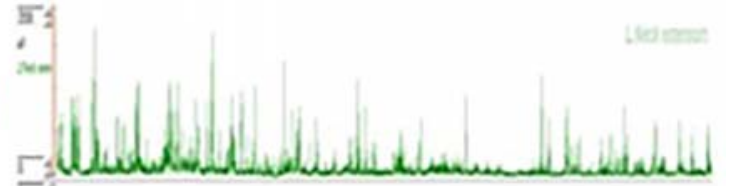

(b) Çalış̧ma durumu tepe (peak) değerleri (Peak value of working position)

Şekil 6. EMG için örnek ölçüm sonucu (sol boyun ekstansörü) (An example result of EMG measurement (left neck extensor))

fazla olduğu görülmektedir. İşin tekrarlayan hareketler içermesi ve uzun süre ayakta çalışılmasını gerektirmesi nedeniyle gün içerisinde bu bölgelerdeki zorlanmaların daha da arttığ değerlendirilmektedir.

Tablo 6. REBA analiz sonuçları (Results of REBA analysis)

\begin{tabular}{ll}
\hline Vücut Bölümü & Puan \\
\hline Gövde & 4 \\
Boyun & 3 \\
Bacaklar & 3 \\
Üst Kol & 5 \\
Alt Kol & 2 \\
Bilek & 2 \\
Reba Skoru & 10 \\
Risk Seviyesi & Yüksek Düzey Risk \\
\hline
\end{tabular}

Tablo 7. AMS analiz sonuçları (Results of AMS analysis)

\begin{tabular}{llll}
\hline $\begin{array}{l}\text { Vücut } \\
\text { Bölümü }\end{array}$ & $\begin{array}{l}\text { Puan } \\
\text { (Nötr } \\
\text { Durum) }\end{array}$ & $\begin{array}{l}\text { Puan } \\
\text { (Eklem } \\
\text { Reaksiyon } \\
\text { Kuvveti) }\end{array}$ & $\begin{array}{l}\text { Şekil } \\
\text { Numaras1 }\end{array}$ \\
\hline $\begin{array}{l}\text { Sol Glenohumeral } \\
\begin{array}{l}\text { Eklem Reaksiyon } \\
\text { Kuvveti (N) } \\
\text { Ayak Eklem }\end{array}\end{array}$ & 20,56 & 144,01 & $5 . a)$ \\
$\begin{array}{l}\text { Reaksiyon Kuvveti } \\
\text { (N) }\end{array}$ & 0,08 & 36,43 & $5 . b)$ \\
$\begin{array}{l}\text { L4-L5 Eklem } \\
\text { Reaksiyon Kuvveti } \\
\text { (N) }\end{array}$ & 32,36 & 202,45 & $5 . b)$ \\
$\begin{array}{l}\text { Sağ Glenohumeral } \\
\text { Eklem Reaksiyon }\end{array}$ & 20,56 & 102,34 & 5.c) \\
Kuvveti (N) & & & \\
\hline
\end{tabular}

Yapılan REBA ve AMS analizlerinde, belirli bir gözlem süresi boyunca gözleme dayalı olarak ergonomik olmayan anlık çalışma pozisyonları dikkate alınmıştır. Ancak gözlenen çalışan, bu süre boyunca sürekli aynı harekete bağlı zorlanmaya değil, farklı pek çok zorlanmalara maruz kalmaktadır. REBA ve AMS ile değerlendirilen anlık zorlanmalar yerine belirli bir çalışma süresi boyunca ortaya çıkan zorlanmanın değerlendirilebilmesi için EMG analizleri yapılmış ve örnek bir analiz sonucu Şekil 6'da verilmiştir.

EMG ölçümlerinde yapılan işler gözlenmiş ve en çok zorlanmaların oluşacağı kaslar değerlendirilmiştir. $\mathrm{Bu}$ kaslarda oluşan zorlanmalar çalışma süresince ölçülmüş ve ayak, boyun, bel, bilek ve üst kolda tepe değerlere ulaştığı, bu vücut bölgelerinde zorlanmaların fazla olduğu görülmüştür. Geliștirilen yöntem ile analizlerde kullanılan yöntemler karşılaştırıldığında; vücut bölgelerinin birebir aynı isim ile değerlendirilmediği görülmüştür. RDMMY'deki omuz, sirt ve bel; REBA'da gövdeye karşılık gelmektedir. REBA'da gövde olarak risk puanı verilirken, AMS'de gövdeyi temsilen belde (L4-L5 omurları) oluşan zorlanmalar incelenebilmektedir. REBA'da üst kol değerlendirilirken göz önünde bulundurulan omuzlar, AMS'de Glenohumeral olarak değerlendirilebilmektedir. REBA'da ayaklar üzerinde duruş bacaklar kategorisinde puanlanırken, AMS'de ayaklardaki zorlanmaların analizi yapilabilmektedir. RDMMY değerlendirme sonucunda ayak, boyun, omuz, sirt ve bel bölgelerinde yüksek risk hesaplanmış, REBA yöntemi sonucunda gövde ve bacaklarda zorlanmaların fazla olduğu görülmüştür. Gerçekleştirilen montaj işlemleri için AMS ile de analizler yapılmıştır. Elde edilen sonuçlarda boyun, bel ve ayaklarda zorlanmalar yüksek bulunmuştur (Tablo 7). AMS analiz sonuçları anket ve REBA ile elde edilen değerleri doğrular niteliktedir. $\mathrm{Bu}$ çalışmaları takiben objektif değerlendirmeler yapılmasına imkan tanıyan EMG ile kaslarda oluşan gerilmeler ölçülmüştür. Tüm bu değerlendirmelerin sonucunda elde edilen bulguların örtüştüğü ve birbirini destekleyici özellikte olduğu değerlendirilmiştir. Analiz edilen vücut bölümlerinin EMG analiz sonuçları Tablo 8'de özetlenmiştir.

Tablo 8. EMG analiz sonuçları (Results of AMS analysis)

\begin{tabular}{ll}
\hline Vücut Bölümü & Puan \\
\hline Sol Soleus (Arka Bacak) & 590 \\
Sağ Soleus (Arka Bacak) & 1150 \\
Sol Tibialis Anterior (Ön Bacak) & 1052 \\
Sağ Tibialis Anterior (Ön Bacak) & 870 \\
Sol Boyun Ekstansörü & 3467 \\
Sağ Boyun Ekstansörü & 3334 \\
Sol Bel Multifidus & 3118 \\
Sağ Bel Multifidus & 3684 \\
Sol Bilek Fleksörü & 1239 \\
Sol Bilek Ekstansörü & 1120 \\
Sağ Bilek Fleksörü & 1240 \\
Sağ Bilek Ekstansörü & 4355 \\
Sol Biceps (Ön Üst Kol) & 947 \\
Sol Triceps (Arka Üst Kol) & 710 \\
Sağ Biceps (Ön Üst Kol) & 1463 \\
Sağ Triceps (Arka Üst Kol) & 742 \\
\hline
\end{tabular}




\section{SONUÇLAR (CONCLUSIONS)}

Bu çalışmada, iş ortamından kaynaklı KİSR'larının azaltılmasına yönelik olarak yapilacak ergonomik düzenlemelerde, hangi vücut bölümlerinin öncelikli olarak dikkate alınması gerektiğini tespit etmek amacıyla yeni bir Ergonomik Risk Değerlendirme Yöntemi önerilmiştir. Önerilen RDMMY risk skoru hesaplarken; literatürde önerilen yöntemlerde yaygın olarak dikkate alınan ağrının yaşanma sıklığı (frekans) ile şiddetinin yanında farklı olarak ağrınınişle ilgisi ve etkilenen kişi yoğunluğunu da birlikte değerlendiren bir yöntemdir. Ayrıca, kesin skor değerleri ile ifade edilmesi zor olan ancak yoğun olarak kullanılan olasılık bileşeni yerine, ölçülebilen bileşenler kullanılması da yöntemin risk skorlarının güvenilirliğini arttırmaktadır. Geliştirilen bu yöntem, genel bir risk değerlendirme yönteminden ziyade, ergonomik riskleri değerlendirmeye yönelik bir yöntemdir ve çalışma ortamında, KİSR'larının azaltılmasına yönelik toplu koruma önlemlerinin odaklanması gereken vücut bölümlerini belirlemek için kullanılmaktadır. Dolayısıyla yöntemin uygulanabilmesi için belirli sayıda çalışanla anket yoluyla veri toplanması gerekmektedir. Bu amaçla, Cornell Üniversitesi tarafından geliştirilmiş olan anket, RDMMY'ne uygun veri sağlayacak şekilde modifiye edilmiş ve montaj hattı çalışanları üzerinde uygulanmıştır.

Önerilen yöntem otomotiv yan sanayisi olarak faaliyet gösteren bir kablo demetleme firmasında seçilen bir montaj hattının ergonomik olarak yeniden tasarımının yapılabilmesi amacıyla uygulanmış, ilgili hat çalışanlarının çalışma koşulları analiz edilmiştir. $\mathrm{Bu}$ amaçla 43 montaj hattı çalışanının boyun, omuz, sırt, bel, üst kol, önkol, dirsek, bilek, kalça, uyluk, diz, baldır, ayak ve değişik el bölgelerine ait hissedilen rahatsızlıklar Cornell Kas İskelet Rahatsızlık Anketi'nin uyarlaması kullanılarak belirlenmiştir. Geliştirilen RDMMY'nin uygulanması sonucunda sağ ve sol ayakta yüksek düzey risk; boyun, omuz, sirt ve bel bölgelerinde ise orta düzey risk hesaplanmıştır. Diğer incelenen vücut bölgelerindeki risk düzeyi ise önerilen RDMMY'ye göre kabul edilebilir sınırlar içerisinde yer almıştır. Sonuçların doğrulaması REBA, AMS ve EMG ölçümleri ile yapılmıştır. Doğrulama sonunda RDMMY'nin sonuçlarının tutarlı olduğu görülmüştür. Geliştirilen yöntem KİSR'de risk değerlendirme amaciyla güvenle kullanılabilir. İlerleyen çalışmada seçilen kablo demetleme montaj hattının yeni tasarımında yüksek ve orta düzey riskli olarak değerlendirilen bölgelerdeki risk düzeylerinin azaltılmasına odaklanilacaktır.

\section{TEŞEKKÜR (ACKNOWLEDGEMENT)}

Bu çalışma 0650.STZ.2014 numaralı "Kablo Demetleme Konveyör Hattında Bilgisayar Destekli Ergonomi Analizleriyle İyileştirmeler" başl1klı SANTEZ projesi kapsamında desteklenmektedir. Çalışmaya katkıları nedeniyle Nursan Kablo Donanımları Sanayi ve Ticaret Anonim Şirketi 'ne teşekkür ederiz.

\section{KAYNAKLAR (REFERENCES)}

1. Luttmann A. Jager M. Gaffler G. Liebers F., Steinberg U., Preventing Musculoskeletal Disorders in the Workplace, World Health Organization Protecting Workers' Health Series no: 5, World Health Organization, Geneva, 2003.

2. Baykasoğlu A., Demirkol A.Ş., Ergonomic Assembly Line Balancing, Journal of the Faculty of Engineering and Architecture of Gazi University, 29 (4), 785-792, 2014.

3. Akay D., Kurt M., Dağdeviren M., Ergonomic Analysis of Working Postures, Journal of the Faculty of Engineering and Architecture of Gazi University, 18 (3), 73-84, 2003.

4. Can G.F., Atalay K.D., Eraslan E., Working Posture Analysis in Fuzzy Environment and Ergonomic Work Station Design Recommendations, Journal of the Faculty of Engineering and Architecture of Gazi University, 30 (3), 451-460, 2015.

5. Fine G.F., Mathemtical Evaluations For Controlling Hazards, J. Saf. Res., 3 (4), 157-166, 1971.

6. Kinney G.F., Wiruth A.D., Practical Risk Analysis for Safety Management, US Naval Postgraduate School and Security Department China Lake, California, 1976.

7. Babuţ G., Moraru R., Cioca L., Kinney-Type Methods: Useful or Harmful Tools in the risk assessment and management process?, International Conference on Manufacturing Science and Education-SIBIURomania, 315-318, 02-05.06.2011.

8. Stankovic M., Stankovic V., Comparative Analysis of Methods for Risk Assessment-Kinney and Auva, Safety Engineering, 3 (3), 129-136, 2013.

9. Gurcanli G.E., Bilir S., Sevim M., Activity based risk assessment and safety cost estimation for residential building construction projects, Safety Science, 80, 1$12,2015$.

10. Oturakçı M., Dağsuyu C., Kokangül A., A new approach to fine kinney method and an implementation study, Alphanumeric Journal, 3 (2), 83-92, 2015.

11. Akdağ C.H., Aybüke U., Sezgin U., Risk Analysis for Occupational Health and Safety and Risk Improvement: A Case Study in an Electric Electronic Company, Journal of Economics, Business and Management, 4 (9), 515-522, 2016.

12. Kokangül A., Polat U., Dağsuyu C., A new approximation for risk assessment using the AHP and Fine Kinney methodologies, Safety Science, 91, 24-32, 2017.

13. Özkı1lıç Ö., İş Sağlığı Ve Güvenliği, Yönetim Sistemleri Ve Risk Değerlendirme Metodolojileri, Ajans-Türk Basın ve Basım A.Ş., 246, Ankara, 2005.

14. MIL_STD_882-D, Department of Defence Standard Practice for System Safety. USA Dept. of Defence, 2000.

15. Woodruff J.M., Consequence and likelihood in risk estimation: A matter of balance in UK health and safety risk assessment practice, Safety Science, 43, 345-353, 2005. 
16. Cox L.A.T., What's Wrong with Risk Matrix?, Risk Analysis, 28 (2), 497-512, 2008.

17. Ristic D., A Tool for Risk Assesment, Safety Engineering, 3 (3), 121-127, 2013.

18. Duijm N.J., Recommendations on the use and design of risk matrices, Safety Science, 2015, DOI: 10.1016/j.ssci.2015.02.014

19. ICAO, Safety Management Manual (SMM), Document 9859, International Civil Aviation Organization, 2013.

20. ISO 17666, Space Systems Risk Management. International Standards Organization, 2003.

21. NASA, Risk Management Reporting. GSFC-STD0002, Goddard Space Flight Center, National Aeronautics and Space Administration, 2009.

22. Kuorinka I., Jonsson B., Kilbom A., Vinterberg H., Biering-Sørensen F., Andersson G., Jørgensen K., Standardised Nordic Questionnaires for the Analysis of Musculoskeletal Symptoms, Appl. Ergon., 18 (3), 233237, 1987.

23. Chandrasakaran A., Chee H.L., Rampal K.G., Tan G. L.E., The Prevalence of Musculoskeletal Problems and Risk Factors Among Women Assembly Workers in the Semiconductor Industry, Medical Journal of Malaysia, 58 (5), 657-666, 2003.

24. Simu M.R., Bocănet V.I., Mesaroş M., Borzan C., Study of the Frequency of Musculoskeletal Disorders Among Dentists, Acta Medica Transilvanica, 2 (4), 271-273, 2014.

25. Smith D.R., Mihashi M., Adachi Y., Koga,H., Ishitake T., A Detailed Analysis of Musculoskeletal Disorder Risk Factors Among Japanese Nurses, J. Saf. Res., 37 (2), 195-200, 2006.

26. Pugh J.D., Gelder L., Williams A.M., Twigg D.E., Wilkinson A.M., Blazevich A.J., Validity and Reliability of an Online Extended Version of the Nordic Musculoskeletal Questionnaire (NMQ-E2) to Measure Nurses' Fitness, Journal of Clinical Nursing, 24, 3550-3563, 2015.

27. Kahraman T., Genç A., Göz E., The Nordic Musculoskeletal Questionnaire: Cross-Cultural Adaptation into Turkish Assessing its Psychometric Properties, Disability and Rehabilitation, 37, 1-8, 2015.

28. Hildebrandt V.H., Prevention of work related musculoskeletal disorders: setting priorities using the standardized Dutch Musculoskeletal Questionnaire, Doctoral Dissertation, Delft University of Technology, Delft, 2001.

29. Hildebrandt V.H., Bongers P.M., Van Dijk F.J.H., Kemper H.C.G., Dul J., Dutch Musculoskeletal Questionnaire: Description and Basic Qualities, Ergonomics, 44 (12), 1038-1055, 2001.

30. Ikhar D., Deshpande V., Untawale S., Work Related Musculoskeletal Disorders in Cotton Spinning Occupation: An Ergonomic Intervention, International Journal on Theoretical and Applied Research in Mechanical Engineering, 2 (4), 17-20, 2013.

31. Vahdati S.S., Khiavi R.S., Ghafouri R.R., Adimi I., Evaluation of Prevalence of Low Back Pain Among
Residents of Tabriz University of Medical Sciences in Relation With Their Position in Work, Turkish Journal of Emergency Medicine, 14 (3), 125-129, 2014.

32. Bos E., Krol B., Van der Star L., Groothoff J., Risk Factors and Musculoskeletal Complaints in NonSpecialized Nurses, IC Nurses, Operation Room Nurses, and X-Ray Technologists, International Archives of Occupational and Environmental Health, 80 (3), 198-206, 2007.

33. Hedge A., Morimoto S., Mccrobie D., Effects of Keyboard Tray Geometry on Upper Body Posture and Comfort, Ergonomics, 42 (10), 1333-1349, 1999.

34. Menzel N.N., Manual handling workload and musculoskeletal discomfort in nursing personnel, Doctoral Dissertation, University of South Florida, College of Public Health, Department of Environmental and Occupational Health, Florida, 2001.

35. Jansen K., Luik M., Reinvee M., Viljasoo V., Ereline J., Gapeyeva H., Pääsuke M., Musculoskeletal Discomfort in Production Assembly Workers, Acta Kinesiologiae Universitatis Tartuensis, 18, 102-110, 2012.

36. Erdinc O., Hot K., Ozkaya M., Turkish Version of the Cornell Musculoskeletal Discomfort Questionnaire: Cross-Cultural Adaptation and Validation, Work, 39 (3), 251-260, 2011.

37. Cornell University. Cornell Musculoskeletal Discomfort Questionnaires (CMDQ). http://ergo.human.cornell.edu/ahmsquest.html. Erişim tarihi Nisan 1, 2015.

38. Marhavilas P.K., Koulouriotis D., Gemeni V., Risk Analysis and Assessment Methodologies in the Work Sites: on a Review, Classification and Comparative Study of the Scientific Literature of The Period 20002009, Journal of Loss Prevention in the Process Industries, 24 (5), 477-553, 2011.

39. Cox S. ve Tait R., Safety, Reliability and Risk Management: An Integrated Approach, Second Edition, Butterworth- Heinemann, Oxford, 1998.

40. Supciller A.A., Abali N., Occupational Health and Safety Within the Scope of Risk Analysis with Fuzzy Proportional Risk Assessment Technique (Fuzzy Prat), Quality and Reliability Engineering International, 31 (7), 1137-1150, 2015.

41. Birgören B., Fine-Kinney risk analizi yöntemiyle risk faktörlerinin hesaplama zorlukları ve çözüm önerileri, Uluslararası Mühendislik Araştırma ve Geliştirme Dergisi, 9 (1), 19-25. 2017.

42. Ebrahemzadih M., Halvani G.H., Shahmoradi B., Giahi O., Assesment and risk management of potential hazards by failure modes and effect analysis (FMEA) method in Yazd Steel Complex, Open Journal of Safety Science and Technologies, 127-135, 2014.

43. Hignett S., McAtamney L., Rapid Entire Body Assessment (REBA), Appl. Ergon., 31, 201-205, 2000.

44. Akro Mühendislik. AnybodyTech kas-iskelet modelleme yazılımı. http://www.akromuhendislik.com/content/anybodytech -kas-iskelet-modelleme. Erişim tarihi Nisan 15, 2015. 
45. Taşar B., Kaya T., Gülten A., EMG Tabanlı El

Hareketinin Analizi Aracılı̆̆ ile Robot El

Simülatörünün Kontrolü, IEEE 22nd Signal Processing and Communications Applications Conference, Trabzon-Turkey, 389-392, 2014. 